\title{
Smart beta Strategy and Long-Short Factor Investing in Style Rotation
}

\author{
Ryumi Kim** \\ Research Source, Institute of Finance and Banking, Seoul National University
}

\begin{abstract}
$<$ Abstract $>$
According to the literature that an outperforming style changes due to time-varying style premiums, I investigate the dynamic style allocation strategies with Korean stocks under regime switching. I find that value, size, and low volatility are the best styles in the entire sample period. However, low beta and low volatility styles produce superior returns in event regimes, and value and dividend styles outperform in normal regimes. As a result, regimedependent dynamic style allocations outperform the stock market, static equivalent strategies, and all single-style portfolios, both before and after transaction costs. These outperformances are consistent in in-sample and out-of-sample prediction analysis.
\end{abstract}

Keywords: Style Rotation; Smart Beta Strategy; Factor Investing; Regime Switching Model; Dynamic Strategy

JEL Classification: G11, G12, C32

* The author is grateful to Joon-Haeng Lee, and Yeonjeong Ha and seminar participants at the 2018 Korean Securities Association meeting for their helpful comments and suggestions. This research was supported by New Scholars Grant Program from the Korean Securities Association and Mirae Asset in 2017.

** Corresponding Author. Address: Institute of Finance and Banking, Business School, Seoul National University, 1 Gwanak-ro Gwanak-gu, Seoul, Korea, 08826; E-mail: atsam6@snu.ac.kr; Tel: +82-2-880-6855; Fax: +82-2-882-0547.

Received 17 April 2018 Revised 17 July 2018 \& 28 August 2018 Accepted 12 September 2018 


\section{Introduction}

After Fama and French (1992, 1993)'s study that firm characteristics or factors such as size and value have the forecasting power for excess returns, various factors (or styles) are investigated in an academic field and invested in financial industry. Institutional investors utilize styles to make their investment decision. Further, a rapidly growing body of smart beta ETFs (exchange-traded funds) is based on these styles.

The literature examining styles conventionally focuses on long-term performances (Fama and French, 1992, 1993, 2015; Capaul et al., 1993; Jegadeesh and Titman, 1993, 2001; La Porta, 1996; Barber and Lyon, 1997; Lewellen, 1999; Frazzini and Pedersen, 2014). However, the outperforming of styles is not stable over time, and different styles demonstrate disparate time-varying performance. Arshanapalli et al. (1998) find that the sign and degree of value-growth spreads vary year after year in the international equity markets. Kao and Shumaker (1999) identify the monthly and quarterly seasonality for the value-growth spread and address the benefits of equity timing strategies in the U.S. equity markets.

In particular, many researchers report the time variation of style premium is intimately associated with the business cycle or market condition. Lucas, van Dijk and Kloek (2002) show that the impact of styles such as size and book-to-price on future excess stock returns varies considerably over time and find that business cycle oriented approaches exhibit the best overall performance of style rotation. Arshanapalli et al. (2004) document that the time-varying variances of value and momentum factors are related to recession. Beckers and Thomas (2010) find that compensations to style risk are cyclical through bull and bear phases of the markets. In addition, Oertmann (2000), Ahmed et al. (2002), Amenc et al. (2003), Black and McMillan (2005), Arshanapalli et al. (2007), Vliet and Blitz (2011), Hodnett (2014), and Lee and Kim (2017) support the time variations of style premiums.

Therefore, I investigate whether returns on various styles are time varying in the Korean stock market and assess the dynamic style rotation (or allocation) strategies based on these results under regime shifts. If the time variations of style returns exist in the Korean market, style rotation can be an effective portfolio strategy. Arshanapalli et al. (2007) argue that with accurate timing strategies, investors who rotate styles will consistently add value in both up and down markets. Further, the recent studies demonstrate outperformances of style rotation strategies. Jacobs and Levy (1996) show that style rotation strategies using individual securities and indices produce superior returns on the Russell 3000 index. Copeland and Copeland (1999) find that rotating strategies between value and growth equities based on the changing implied 
volatility of options on stock index futures outperform. Levis and Tessaromatis (2004) also report their rotation strategies between value and growth styles generate higher returns in the U.K. market. Further, their higher returns are robust to transaction cost. Ahmed et al. (2002) and Amenc et al. (2003) confirm the superior returns of style rotation strategies.

According to Beckers and Thomas (2010), an ability to forecast the turning points of style investment contributes to the better performance of style rotation. In this paper, regime-switching models are used to capture the time-varying return-risk profiles of styles and to build the dynamic style allocation strategies based on their time variations. Regime-switching models introduced by Hamilton (1989) identify the several regimes based on the statistical characteristics of underlying assets. Since regime shifts reflect variations on return-risk profiles of the underlying asset, regimeswitching models can be effective to dynamically analyze and forecast style premiums if the asset reflects time-varying style returns well. According to Ang and Timmermann (2012), regime-switching models can match the tendency of financial markets to often change their behavior abruptly and the phenomenon that the new behavior of financial variables often persists for several periods after such a change. They also document that the models can be used for ex-ante real-time forecasting, optimal portfolio choice, and other economic applications. Furthermore, much evidence supports the effectiveness of regime switching in dynamic asset allocations. For instance, Ang and Bekaert (2002, 2004) use regime switching for international asset allocation and find their two-state Markov-switching model improves performances of optimized international equity portfolios. Guidolin and Timmermann (2008) propose four-state regimes switching for optimal asset allocation with joint distribution of returns on the market, size (SMB), and book-to-market (HML) portfolios in the U.S. stock market. In addition, Ammann and Verhofen (2006), who estimate a multivariate regime-switching model for the Carhart (1997) four-factor model, show that the outperforming styles vary with regimes identified and discuss style allocation according to the regimes.

In this study, for analysis of time-varying style performances and dynamic style allocations (or rotations), I form style portfolios with Korean equities, which include size, value, momentum, low volatility, low beta, profitability, investment, quality, and dividend factors. All of the style portfolios are formed using two approaches, a longonly approach and a long-short approach, which are weighted by fundamentals or market capitalization. Since most of the smart beta strategy funds that are one of the fastest growing segments of ETF market and have been attracting much attention in recent years are formed with weighting based on desired factor characteristics (or fundamentals) such as book-to-market, dividend, or volatility, rather than market 
capitalization weighting (or value weighting, VW), I apply both weighting schemes to construct portfolios. Moreover, some researchers report that market-cap-weighted portfolios underperform non-cap-weighted portfolios with similar characteristics (Hsu, 2006; Amenc et al., 2009). Also, with the commercial success of fundamental weighting (FW) strategies, there is debate on their pros and cons (Asness, 2006). ${ }^{1)}$ Thus, my two weighting schemes enable comparing their relative performances.

The advantages of long-short portfolios that go long stocks with the desired characteristic and short stocks with the undesired characteristic are zero-investment costs and capturing pure factor premiums, while long-only portfolios that capture returns on top stocks with the desired characteristic cannot totally eliminate initial costs and exposures to the undesired characteristic. Thus, the long-short approach to factor investing facilitates effective factor diversification as they remove much of the market exposure through offsetting short positions, consequently reducing the correlation to the market (Ilmanen and Kizer, 2012). Although the long-only approach correlates with the market more, in practice, many investors implement factor investing using longonly portfolios with investment vehicles such as smart beta indices or ETFs because of benchmark restrictions and implementation costs in long-short strategies (Blitz et al., 2014). Moreover, recent research, including Blitz et al. (2014) and Arnott et al. (2017), reports differences in returns and risk between long-short and long-only strategies. Therefore, strategies in this paper use both approaches to factor or style investing.

In fact, products based on the smart beta strategy whose representative form is the long-only fundamentally weighted portfolio have experienced tremendous growth in recent years worldwide. The smart beta funds are generally managed as ETFs rather than mutual funds. According to Morningstar (2017), as of June 30, 2017, assets in smart beta ETPs (exchange-traded products) including ETFs grew 28.3\% worldwide during the previous year. ${ }^{2)}$ Especially, assets in Asia-Pacific smart beta ETPs grew $61.4 \%$ during the same period, which is a faster pace than in any other regions. Korea is the third largest smart beta market in terms of AUM (asset under management), after Japan and Australia, and has the largest number of smart beta ETPs. As the Korean smart beta ETPs market also continues to grow, research for the style investing strategies in the Korean market is necessary.

The paper is organized as follows. Section 2 describes the sample collection and portfolio formation methodology for style investing. Section 3 provides the statistics

1) See also Haugen and Baker (1991), Treynor (2005), Siegel (2006), Arnott and Hsu (2007), Chen et al. (2007), Ranaldo and Häberle (2007), Perold (2007), Estrada (2008), and Kaplan (2008) for the market capitalization weighting versus fundamental weighting.

2) Morningstar prefers to refer to these products as "strategic-beta", not smart beta. 
and performances of style portfolios in the entire period and subperiods. Section 4 represents regime-switching models for the dynamic style allocation and estimates the models using various macroeconomic variables. Section 5 explains my dynamic style allocation strategies and their results. Section 6 concludes.

\section{Formation of Style Portfolios}

For the analysis of time-varying style premiums and style allocations, I use all nonfinancial firms traded on the KOSPI market of the Korean Exchange from July 1986 to June 2017. Mutual funds, REITs, ETFs, and preferred stocks are excluded, and only the December fiscal year-end firms are used. Negative book equity firms are eliminated. ${ }^{3)}$ Additionally I exclude data for two years after firms are listed and for two years before firms are delisted. I obtain all data for this study from DataGuide, including monthly stock returns, market capitalizations, accounting data, and market returns. I use the KOSPI index as a proxy for the value-weighted market returns, and the 364-day monetary stabilization bond (MSB) rate as a proxy for the risk-free rate.

Style portfolios are generally formed as $2 \times 3$ portfolios following typical definitions from various studies such as Fama and French (1993, 2015), French (2017), and Blitz et al. (2014). I divide all stocks by the various factor signals to construct desiredcharacteristic and undesired-characteristic groups. Desired-characteristic groups are constructed from stocks above the 70th percentile by the style sort, and undesiredcharacteristic groups are constructed from stocks below the 30th percentile, except size style. Two size groups, 'Big' and 'Small' are formed from stocks by the median value of firm size. The intersections of the two size groups and three groups of other styles produce six portfolios. Each of the six portfolios is weighted by market-cap for general factor investing or by fundamental for the smart beta strategy except smallsize style.4) The long-side portfolio is the average of the returns on the Big/desiredcharacteristic portfolio and the Small/desired-characteristic portfolio. The short-side portfolio is the average of the two undesired-characteristic portfolio returns. The long-side portfolio for size is the Big group and the short-side portfolio for size is the Small group. Consequently, the return on the long-short portfolio is the long-side

3) I also use all firms including financial and all fiscal year-end firms for the equivalent analysis. The findings do not significantly differ with the results from the analysis with the main dataset; however, almost all style premiums using the main dataset are slightly higher than using all firms. The size premium using the main dataset is lower.

4) According to the FW methodology for the smart beta strategy, the small-size smart beta strategy should be weighted by $1 /$ size; however, it is not possible or practical to buy smaller-size firms more due to infrequent trading or nonsynchronous trading. Thus, the FW portfolios for size style are equal-weighted. 
portfolio return minus the short-side portfolio return, and the return on the long-only portfolio is the long-side portfolio return.

Analyzed styles in this paper are size, value, momentum, low volatility, low beta, profitability, investment, quality, and dividend, which are traditional factors or attracting much attention in Korea. Since size, value, profitability, and investment are established Fama-French factors in Fama and French (1993, 2015), they are firstly included in my study. Size and value are especially distinguished factors in both Korean and many stock markets. Also, considerable literature using Korean stock data reports that low volatility, low beta, and dividend are outperforming. Their outperformances are employed in financial industry. Morningstar (2017) documents that dividend, value, and low volatility are the top three smart beta attributes in order of the number of ETFs in the Korean market. Momentum is involved in this paper as the Korea Exchange (KRX) announces momentum indices and related ETFs are quite traded, although significance of performance from momentum in Korea is debatable. Additionally, I investigate quality that has been attracting much attention in recent years and traded as ETFs and funds in Korean market. Other factors except styles included in this study, such as illiquidity, interest investors less, and thus, do not have related indices or ETFs in the KRX.

Fundamental measures for security selection in the portfolios and FW scheme are always positive in cases of size, value, volatility, and dividend but can be negative for some stocks in cases of momentum, beta, profitability, investment, and quality. Thus, the negative-possible fundamental measures are modified to positive-constrained fundamental scores for positive portfolio weighting. To begin with, Z-scores are calculated as follows:

$$
Z_{F, i, t}=\frac{X_{F, i, t}-\mu_{F, t}}{\sigma_{F, t}}
$$

where $Z_{F, i, t}$ is the Z-score for factor $F$ of stock $i$ in year $t, X_{F, i, t}$ is the proxy (fundamental measure) for factor $F$ of stock $i$ in year $t, \mu_{F, t}$ is the mean of the proxy for factor $F$ in year $t$, and $\sigma_{F, t}$ is the standard deviation of the proxy for factor $F$ in year $t$. The fundamental scores are then computed from the Z-Score as follows:

$$
\text { Fundamental Score }= \begin{cases}1+Z_{F, i, t}, & \text { if } Z_{F, i, t} \geq 0 \\ \left(1+Z_{F, i, t}\right)^{-1}, & \text { if } Z_{F, i, t}<0\end{cases}
$$

FW portfolios of the smart beta strategy for momentum, beta, profitability, investment, and quality are weighted by these fundamental scores, which are a widely used method to construct smart beta indices by many index providers such as KOSPI, MSCI, and FTSE Russell. 
These portfolios are rebalanced annually each July. As I mentioned before, size, value, momentum, low volatility, low beta, profitability, investment, quality, and dividend factors are considered in this paper, and details to form style portfolios are as follows.

- Size: With firm's market capitalization measured at the end of June in year $\tau$, the securities with larger size than the median firm size are assigned into the Big group, and those with a smaller size than the median are assigned into the Small group. The stocks are market-cap weighted or equally weighted, within each of the two groups, which are used to form the long-side and short-side portfolio.

- Value: I use the book-to-market equity ratio for the value measure. The market capitalization of common stock at the end of December of $\tau-1$ and the book common equity for the fiscal year ending in the calendar year $\tau-1$ are used to calculate the book-to-market equity ratio. The long-side and the short-side portfolios are formed from the Big and Small stocks with the top $30 \%$ and with the bottom $30 \%$ of the book-to-market equity ratio. The stocks are market-cap weighted or book-to-market-ratio weighted, within each of the two portfolios.

- Momentum: Prior (2-12 months) stock returns at the end of June in year $\tau$ are sorted. The long-side and short-side portfolios are constructed similar to value portfolios but are market-cap weighted or momentum-score weighted, which is calculated by equation (2).

- Low volatility: Haugen and Baker (1991), Chan et al. (1999), Jagannathan and Ma (2003), and Clarke et al. (2006) document that low volatility stocks (based on average total volatility or beta) in the U.S. and global markets outperform. The measure for low volatility here is the volatility of past daily returns over one year at the end of June in year $\tau$. Portfolios are market-cap weighted or $1 /$ volatility weighted.

- Low beta: Market betas of individual stocks for the end of June in year $\tau$ are estimated using the preceding one year (six-month minimum) of daily excess returns on KOSPI index and individual stocks. FW portfolios for low beta style are 1/(beta score) weighted, which is calculated using equation (2).

- Profitability: Following Fama and French (2015) methodology, profitability in the sort for June of year $\tau$ is measured with accounting data for the fiscal year ending in year $\tau-1$ and is revenues minus cost of goods sold, minus selling, general, and administrative expenses, minus interest expense all divided by book common equity. FW portfolios are profitability-score weighted, which is calculated using equation (2). 
- Investment: Titman et al. (2013) and Fama and French (2015) document that high investment is followed by low average returns in many markets. According to the Fama and French (2015) methodology, investment measure for the end of June in year $\tau$ is the change in total assets from the fiscal year ending in year $\tau-2$ to the fiscal year ending in $\tau-1$, divided by total assets in $\tau-2$. FW portfolios are $1 /$ (investment score) weighted, which is calculated using equation (2).

- Quality: the quality style that has been attracting much attention in recent years captures the excess return of high-quality firms based on profitability, safety, and investment.5) I measure quality with high return on equity (ROE), low debt-toequity ratio, low asset growth, and low earnings variability. ROE is net income over book equity, debt-to-equity ratio is total debt over book equity, and asset growth is equivalent to investment measure. ROE and debt-to-equity ratio for the end of June in year $\tau$ is calculated with accounting data for the fiscal year ending in year $\tau-1$. Earnings variability for the end of June in year $\tau$ is defined as standard deviation of earning per share (EPS) growth over the past five years. Then, the Z-Score for each of the four variables for each security is calculated using equation (1), and the composite quality Z-Score is as follows:

$$
Z_{Q, i, t}=Z_{R O E, i, t}-Z_{D E, i, t}-Z_{A G, i, t}-Z_{E V o l, i, t}
$$

where $Z_{Q, i, t}$, is the composite quality Z-Score of stock $i$ in year $t, Z_{R O E, i, t}$, is the ROE Z-Score of stock $i$ in year $t, Z_{D E, i, t}$ is the debt-to-equity ratio Z-Score of stock $i$ in year $t, Z_{A G, i, t}$, is the asset growth Z-Score of stock $i$ in year $t$, and $Z_{E V o l, i, t}$, is the earnings variability Z-Score of stock $i$ in year $t$. If earnings variability is missing, $Z_{Q, i, t}$, is calculated using ROE, debt-to-equity ratio, and asset growth Z-Scores. Finally, quality score is calculated using the composite quality Z-Score and the equation (2). The stocks are market-cap weighted or quality-score weighted within each of the portfolios.

- Dividend: Litzenberger and Ramaswamy (1979), Blume (1980), and Fama and French (1988) find evidence for a positive relationship between stock returns and

5) There are many methodologies for the quality measure. The MSCI Quality Index is based on high ROE, stable earnings, and low debt-to-equity ratio. The S\&P Quality LargeMidCap Index selects stocks of high ROE, low financial leverage, and low accruals. RAFI Quality Factor Index is constructed from the top $25 \%$ of firm size with high profitability (based on operating profitability, ROE, and ROA) and low investment (based on asset growth and book growth). The KRX Smart Quality Index of the Korea Exchange uses ROE, gross operating asset growth, and financial leverage as the quality measure. Asness, Frazzini, and Pedersen (2017) suggest measuring quality with gross profits over assets, ROE, ROA, cash flow over assets, gross margin, accruals, their growth, beta, leverage, bankruptcy risk, and ROE volatility. 
the dividend yield. I use the dividend yield for the fiscal year ending in year $\tau-1$ for the high dividend measure for the end of June in year $\tau$, which is the dividend overstock price. Dividend portfolios are market-cap weighted or dividendyield weighted. If the dividend yield of the security is zero, the dividend yield is assumed infinitesimal because the short side portfolios in some years involve a number of zero-dividend firms.

$<$ Table $1>$ presents a summary of nine styles that are investigated in this paper, including their measures, possible signs of measures, and weighting schemes for fundamental weighting.

〈Table 1〉 Summary of Style Portfolio Formation

This table shows the summary of style portfolio formation scheme.

\begin{tabular}{|c|c|c|c|}
\hline Styles & Measure & $\begin{array}{c}\text { Possible } \\
\text { signs }\end{array}$ & $\begin{array}{l}\text { Weighting Scheme } \\
\text { for FW }\end{array}$ \\
\hline Size & Market capitalization & + & Equally weighting \\
\hline Value & Book-to-market ratio & + & $\begin{array}{l}\text { Book-to-market } \\
\text { ratio }\end{array}$ \\
\hline Momentum & Prior $12-1$ monthly returns & $+/-$ & Momentum score \\
\hline Low volatility & $\begin{array}{l}\text { Standard deviation of the past } 1 \text {-year daily } \\
\text { stock returns }\end{array}$ & + & 1/volatility \\
\hline Low beta & $\begin{array}{l}\text { Market beta estimated using past } 1 \text {-year } \\
\text { daily excess returns on stocks and market }\end{array}$ & $+/-$ & 1/beta score \\
\hline Profitability & $\begin{array}{l}\text { (Revenues minus cost of goods sold, minus } \\
\text { selling, general, and administrative } \\
\text { expenses, minus interest expense)/book } \\
\text { common equity }\end{array}$ & $+/-$ & Profitability score \\
\hline Investment & Asset growth & $+/-$ & $1 /$ Investment score \\
\hline Quality & $\begin{array}{l}\text { ROE, debt-to-equity ratio, asset growth, and } \\
\text { past } 5 \text {-year earnings variability }\end{array}$ & $+/-$ & Quality score \\
\hline Dividend & Dividend yield & + & Dividend yield \\
\hline
\end{tabular}

\section{Performances of Style Portfolios}

First, I investigate the performances of all style strategies for the entire sample period. Panels A and B of <Table $2>$ show the performances on long-only and long-short portfolios of styles with VW and FW schemes. According to the Panel A of the longonly approach, the average returns on all strategies are $1.093 \% \sim 2.066 \%$ and higher than the average return on the KOSPI index, $0.851 \% .14$ of 18 style strategies have 
significant positive market-adjusted returns.6) Value (FW) produces the highest average return and the highest average market-adjusted return of $1.215 \%$, and momentum (VW) produces the lowest average return and average market-adjusted return. Value, size, dividend, and low beta are the best performers among FW portfolios in return order, and value, dividend, and low volatility are the best performers among VW portfolios in return order. Sharpe ratios of all strategies are higher than that of the KOSPI index, which shows that style investment strategies generate higher reward to risk than the market. In particular, low volatility and low beta have the highest Sharpe ratios due to their relatively low risk. Value and dividend have the highest information ratios (IR), among FW portfolios. Low volatility and value have the highest Sharpe ratios, and value and profitability have the highest IRs, among VW portfolios. Overall, value style is the best in the Korean market during the entire period regardless of weighting schemes. The FW size portfolio outperforms other styles and market but is highly risky. Low volatility is also stable and good to invest in. Comparing FW and VW strategies, FW portfolios of all styles produce superior returns and Sharpe ratios than VW portfolios. As all style premiums are higher than market premium, FW approaches can expand their style effect on performances. This evidence supports the recent growth of smart beta ETFs and funds using alternative weighting including FW.

$<$ Table $2>$ also reports the downside risk of the portfolios. Downside STD in <Table $2>$ is the semi-deviation of excess returns with respect to a threshold of zero. The semi-deviation is calculated similar to standard deviation, but only returns that are below the threshold are taken into account. The Sortino ratio is the average excess return divided by the downside STD. Although the long-only portfolios from FW approaches are riskier in terms of downside STDs, Sortino ratios of all long-only FW portfolios are higher than those of the VW portfolios for equal styles, implying that they significantly compensate for the downside risk. This result is supported by drawdown analysis. According to Amenc et al. (2009), the risk an investor is taking is that portfolios may actually yield losses over sustained periods of time. Thus, they look at the drawdown as the underperformance with respect to the benchmark and

6) As negative book equity firms and data for two years after firms are listed and for two years before firms are delisted are eliminated, average of average monthly returns on all sample firms is different with the average KOSPI index return. Value-weighted and equal-weighted averages of monthly returns on all firms in the sample are about $1.3 \%$ and $1.6 \%$, which are higher than the average KOSPI index return. Thus, returns on not only long-side portfolios but also short-side portfolios for almost all styles are higher than the KOSPI index return. 


\section{〈Table 2〉 Performances of Styles During the Entire Sample Period}

This table shows performances of long-only and long-short portfolios of styles during the entire sample period. Panels A and B present performances of long-only and long-short portfolios for styles. FW is fundamental-weighted portfolios and VW is value-weighted portfolios. Exc. return is excess return, which is the portfolio's monthly return minus the monthly risk-free rate, MSB. Mrk-adj. return is market-adjusted return, which is the portfolio's monthly return minus the monthly return on the KOSPI index. Sharpe ratio refers to excess returns divided by STD. IR (information ratio) is the market-adjusted returns divided by their standard deviations in Panel A, and long-short returns divided by their standard deviations in Panel B. Downside STDs is the semi-deviations of excess returns in Panel A and long-short returns in Panel B, with respect to a threshold of zero. Sortino ratio is average excess returns (Panel A) or long-short returns (Panel B) divided by the downside STD. In addition, the maximum drawdown and the duration of the longest drawdown in months are presented. The $t$-statistics are reported in parentheses. The sample period is from July 1987 to June 2017.

Panel A: Long-only portfolios

\begin{tabular}{|c|c|c|c|c|c|c|c|c|c|c|c|c|c|}
\hline Style & & $\begin{array}{l}\text { Mean } \\
(\%)\end{array}$ & $\begin{array}{l}\text { STD } \\
(\%)\end{array}$ & $\begin{array}{c}\operatorname{Max} \\
(\%)\end{array}$ & $\begin{array}{l}\text { Min } \\
(\%)\end{array}$ & $\begin{array}{l}\text { Exc. } \\
\text { return } \\
(\%)\end{array}$ & $\begin{array}{l}\text { Mrk- }^{-} \\
\text {adj. } \\
\text { return } \\
(\%)\end{array}$ & $\begin{array}{c}\text { Sharpe } \\
\text { ratio }\end{array}$ & IR & $\begin{array}{c}\text { Down- } \\
\text { side } \\
\text { STD } \\
(\%)\end{array}$ & $\begin{array}{l}\text { Sortino } \\
\text { ratio }\end{array}$ & $\begin{array}{c}\text { Max. } \\
\text { draw- } \\
\text { down } \\
(\%)\end{array}$ & $\begin{array}{c}\text { Longest } \\
\text { draw- } \\
\text { down }\end{array}$ \\
\hline $\begin{array}{r}\text { KOSPI } \\
\text { index }\end{array}$ & & $\begin{array}{l}0.851 \\
(1.96)\end{array}$ & 8.230 & 50.770 & -27.250 & $\begin{array}{l}0.195 \\
(0.45)\end{array}$ & & 0.024 & & 5.010 & 0.039 & & \\
\hline \multirow[t]{2}{*}{ Size } & FW & $\begin{array}{l}2.046 \\
(4.02)\end{array}$ & 9.647 & 52.453 & -39.105 & $\begin{array}{l}1.390 \\
(2.72)\end{array}$ & $\begin{array}{l}1.194 \\
(3.23)\end{array}$ & 0.144 & 0.170 & 6.602 & 0.211 & -25.995 & 57 \\
\hline & VW & $\begin{array}{l}1.406 \\
(2.91)\end{array}$ & 9.179 & 40.434 & -35.606 & $\begin{array}{l}0.750 \\
(1.54)\end{array}$ & $\begin{array}{l}0.554 \\
(1.65)\end{array}$ & 0.082 & 0.087 & 6.284 & 0.119 & -22.496 & 94 \\
\hline \multirow[t]{2}{*}{ Value } & FW & $\begin{array}{l}2.066 \\
(4.03)\end{array}$ & 9.731 & 61.592 & -31.639 & $\begin{array}{l}1.410 \\
(2.74)\end{array}$ & $\begin{array}{l}1.215 \\
(3.74)\end{array}$ & 0.145 & 0.197 & 6.050 & 0.233 & -27.351 & 36 \\
\hline & VW & $\begin{array}{l}1.784 \\
(3.77)\end{array}$ & 8.966 & 48.610 & -27.201 & $\begin{array}{l}1.128 \\
(2.37)\end{array}$ & $\begin{array}{l}0.932 \\
(3.76)\end{array}$ & 0.126 & 0.198 & 5.543 & 0.204 & -21.853 & 64 \\
\hline \multirow[t]{2}{*}{ Momentum } & FW & $\begin{array}{l}1.149 \\
(2.43)\end{array}$ & 8.984 & 53.567 & -38.001 & $\begin{array}{l}0.493 \\
(1.04)\end{array}$ & $\begin{array}{l}0.298 \\
(1.01)\end{array}$ & 0.055 & 0.053 & 6.384 & 0.077 & -24.891 & 115 \\
\hline & VW & $\begin{array}{l}1.093 \\
(2.43)\end{array}$ & 8.534 & 46.873 & -31.509 & $\begin{array}{l}0.437 \\
(0.97)\end{array}$ & $\begin{array}{l}0.241 \\
(1.03)\end{array}$ & 0.051 & 0.054 & 6.007 & 0.073 & -16.481 & 109 \\
\hline \multirow[t]{2}{*}{$\begin{array}{l}\text { Low } \\
\text { volatility }\end{array}$} & $\mathrm{FW}$ & $\begin{array}{l}1.832 \\
(4.75)\end{array}$ & 7.321 & 45.197 & -24.178 & $\begin{array}{l}1.176 \\
(3.02)\end{array}$ & $\begin{array}{l}0.980 \\
(3.58)\end{array}$ & 0.161 & 0.189 & 4.853 & 0.242 & -19.573 & 58 \\
\hline & VW & $\begin{array}{l}1.563 \\
(4.11)\end{array}$ & 7.216 & 49.962 & -26.364 & $\begin{array}{l}0.907 \\
(2.37)\end{array}$ & $\begin{array}{l}0.711 \\
(3.37)\end{array}$ & 0.126 & 0.178 & 4.430 & 0.205 & -18.396 & 75 \\
\hline \multirow[t]{2}{*}{ Low beta } & FW & $\begin{array}{l}1.871 \\
(4.67)\end{array}$ & 7.603 & 44.471 & -26.714 & $\begin{array}{l}1.215 \\
(3.01)\end{array}$ & $\begin{array}{l}1.019 \\
(3.27)\end{array}$ & 0.160 & 0.172 & 4.953 & 0.245 & -18.758 & 58 \\
\hline & VW & $\begin{array}{l}1.253 \\
(3.35)\end{array}$ & 7.090 & 41.514 & -26.411 & $\begin{array}{l}0.597 \\
(1.59)\end{array}$ & $\begin{array}{l}0.402 \\
(1.39)\end{array}$ & 0.084 & 0.073 & 4.558 & 0.131 & -20.372 & 84 \\
\hline \multirow[t]{2}{*}{ Profitability } & FW & $\begin{array}{l}1.696 \\
(3.92)\end{array}$ & 8.217 & 54.887 & -28.505 & $\begin{array}{l}1.040 \\
(2.39)\end{array}$ & $\begin{array}{l}0.844 \\
(3.15)\end{array}$ & 0.127 & 0.166 & 5.261 & 0.198 & -17.963 & 56 \\
\hline & VW & $\begin{array}{l}1.533 \\
(3.70)\end{array}$ & 7.866 & 50.450 & -29.438 & $\begin{array}{l}0.877 \\
(2.11)\end{array}$ & $\begin{array}{l}0.682 \\
(3.70)\end{array}$ & 0.111 & 0.195 & 4.965 & 0.177 & -13.468 & 66 \\
\hline \multirow[t]{2}{*}{ Investment } & FW & $\begin{array}{l}1.729 \\
(3.63)\end{array}$ & 9.043 & 46.543 & -33.193 & $\begin{array}{l}1.073 \\
(2.24)\end{array}$ & $\begin{array}{l}0.878 \\
(3.01)\end{array}$ & 0.119 & 0.159 & 6.148 & 0.175 & -20.083 & 55 \\
\hline & VW & $\begin{array}{l}1.346 \\
(3.05)\end{array}$ & 8.376 & 43.978 & -27.804 & $\begin{array}{l}0.690 \\
(1.56)\end{array}$ & $\begin{array}{l}0.495 \\
(2.21)\end{array}$ & 0.082 & 0.117 & 5.423 & 0.127 & -17.096 & 56 \\
\hline \multirow[t]{2}{*}{ Quality } & FW & $\begin{array}{l}1.803 \\
(4.13)\end{array}$ & 8.292 & 52.318 & -29.226 & $\begin{array}{l}1.147 \\
(2.61)\end{array}$ & $\begin{array}{l}0.952 \\
(3.51)\end{array}$ & 0.138 & 0.185 & 5.551 & 0.207 & -16.840 & 55 \\
\hline & VW & $\begin{array}{l}1.538 \\
(3.78)\end{array}$ & 7.719 & 47.215 & -27.039 & $\begin{array}{l}0.882 \\
(2.16)\end{array}$ & $\begin{array}{l}0.686 \\
(3.20)\end{array}$ & 0.114 & 0.168 & 4.877 & 0.181 & -19.281 & 55 \\
\hline \multirow[t]{2}{*}{ Dividend } & FW & $\begin{array}{l}1.933 \\
(4.21)\end{array}$ & 8.718 & 54.175 & -32.812 & $\begin{array}{l}1.277 \\
(2.76)\end{array}$ & $\begin{array}{l}1.082 \\
(3.69)\end{array}$ & 0.147 & 0.195 & 5.835 & 0.219 & -20.441 & 24 \\
\hline & VW & $\begin{array}{l}1.649 \\
(3.81) \\
\end{array}$ & 8.201 & 56.262 & -29.918 & $\begin{array}{l}0.993 \\
(2.28) \\
\end{array}$ & $\begin{array}{l}0.797 \\
(3.29) \\
\end{array}$ & 0.121 & 0.173 & 5.524 & 0.180 & -15.037 & 56 \\
\hline
\end{tabular}


Smart beta Strategy and Long-Short Factor Investing in Style Rotation

〈Table 2〉 Performances of Styles During the Entire Sample Period (Continued)

Panel B: Long-short portfolios

\begin{tabular}{|c|c|c|c|c|c|c|c|c|c|}
\hline Style & & $\begin{array}{c}\text { Mean } \\
(\%)\end{array}$ & $\begin{array}{l}\text { STD } \\
(\%)\end{array}$ & $\begin{array}{c}\operatorname{Max} \\
(\%) \\
\end{array}$ & $\begin{array}{l}\text { Min } \\
(\%) \\
\end{array}$ & IR & $\begin{array}{l}\text { Downside } \\
\text { STD (\%) }\end{array}$ & $\begin{array}{c}\text { Sortino } \\
\text { ratio }\end{array}$ & $\begin{array}{c}\text { Longest } \\
\text { drawdown }\end{array}$ \\
\hline \multirow[t]{2}{*}{ Size } & FW & $\begin{array}{l}0.820 \\
(3.48)\end{array}$ & 4.469 & 22.585 & -15.741 & 0.183 & 2.529 & 0.324 & 67 \\
\hline & VW & $\begin{array}{l}0.311 \\
(2.07)\end{array}$ & 7.028 & 19.967 & -30.351 & 0.030 & 5.259 & 0.040 & 237 \\
\hline \multirow[t]{2}{*}{ Value } & FW & $\begin{array}{l}0.907 \\
(4.01)\end{array}$ & 4.298 & 36.073 & -13.293 & 0.211 & 2.284 & 0.397 & 56 \\
\hline & VW & $\begin{array}{l}0.942 \\
(3.69)\end{array}$ & 4.844 & 18.446 & -24.906 & 0.195 & 3.124 & 0.302 & 80 \\
\hline \multirow[t]{2}{*}{ Momentum } & FW & $\begin{array}{l}-0.558 \\
(-1.74)\end{array}$ & 6.076 & 17.133 & -66.486 & -0.092 & 5.995 & -0.093 & 303 \\
\hline & VW & $\begin{array}{l}-0.396 \\
(-1.39)\end{array}$ & 5.392 & 17.719 & -33.188 & -0.073 & 4.166 & -0.095 & 303 \\
\hline \multirow[t]{2}{*}{ Low volatility } & FW & $\begin{array}{l}0.547 \\
(1.40)\end{array}$ & 7.428 & 25.557 & -75.596 & 0.074 & 7.148 & 0.077 & 70 \\
\hline & VW & $\begin{array}{l}0.910 \\
(2.46)\end{array}$ & 7.006 & 26.210 & -32.119 & 0.130 & 5.042 & 0.180 & 51 \\
\hline \multirow[t]{2}{*}{ Low beta } & FW & $\begin{array}{l}0.660 \\
(2.23)\end{array}$ & 5.620 & 24.858 & -23.709 & 0.117 & 3.957 & 0.167 & 67 \\
\hline & VW & $\begin{array}{l}0.140 \\
(0.42)\end{array}$ & 6.332 & 30.811 & -31.166 & 0.022 & 4.786 & 0.029 & 99 \\
\hline \multirow[t]{2}{*}{ Profitability } & FW & $\begin{array}{l}0.255 \\
(0.98)\end{array}$ & 4.957 & 20.178 & -35.061 & 0.051 & 4.328 & 0.059 & 76 \\
\hline & VW & $\begin{array}{l}0.474 \\
(1.72)\end{array}$ & 5.237 & 22.098 & -21.540 & 0.090 & 3.689 & 0.128 & 101 \\
\hline \multirow[t]{2}{*}{ Investment } & FW & $\begin{array}{l}0.411 \\
(2.87)\end{array}$ & 2.722 & 11.765 & -8.293 & 0.151 & 1.501 & 0.274 & 51 \\
\hline & VW & $\begin{array}{l}0.283 \\
(1.46)\end{array}$ & 3.683 & 15.137 & -14.105 & 0.077 & 2.324 & 0.122 & 134 \\
\hline \multirow[t]{2}{*}{ Quality } & FW & $\begin{array}{l}0.510 \\
(2.86)\end{array}$ & 3.379 & 15.435 & -21.028 & 0.151 & 2.535 & 0.201 & 64 \\
\hline & VW & $\begin{array}{l}0.679 \\
(3.04)\end{array}$ & 4.235 & 16.434 & -18.178 & 0.160 & 3.022 & 0.225 & 143 \\
\hline \multirow[t]{2}{*}{ Dividend } & FW & $\begin{array}{l}0.507 \\
(1.98)\end{array}$ & 4.868 & 19.812 & -37.646 & 0.104 & 4.241 & 0.120 & 59 \\
\hline & VW & $\begin{array}{l}0.860 \\
(3.36)\end{array}$ & 4.856 & 26.491 & -26.369 & 0.177 & 3.320 & 0.259 & 35 \\
\hline
\end{tabular}

the longest drawdown as sustained periods of cumulative underperformance. Their longest drawdown indicates how long an investor who has chosen his/her investment rather than in the benchmark had to wait in order to recover its underperformance. Following their work, I report the maximum drawdown and the longest drawdown in <Table 2>, which are calculated from style portfolios with respect to the benchmark, the KOSPI index. While almost all long-only FW portfolios, except two styles, suffer from more substantial maximum drawdowns than VW portfolios, 8 of 9 long-only FW portfolios recover their underperformances in a shorter time in terms of the longest drawdown. As a result, long-only FW portfolios have more downside risk; however, they offer larger rewards to the risk than VW portfolios for an equivalent style. 
Since Blitz et al. (2014) and Arnott et al. (2017) report the different returns and risk between long-only and long-short approaches, I analyze the performances of long-short style portfolios and present the results in Panel B of <Table 2>.7) Similar to the long-only approach results, value has the highest average return and IR in both the FW and VW schemes. The size portfolio is the second winner in the FW strategy, and the low volatility and dividend are good in the VW strategy. Remarkable points in long-short approaches are as follows. First, 6 of 9 VW portfolios have higher returns than FW portfolios. Second, low volatility is the riskiest style in longshort strategies, whereas it is the least risky style in long-only strategies. Low volatility is a stable strategy with low risk in the long-only approach, but the low-high volatility spread fluctuates. Thus, investors need to appreciate their different degree of risk according to portfolio forming schemes when investing in styles. Finally, the long-short momentum portfolio generates an insignificant negative return, which is consistent with other studies. ${ }^{8)}$ In addition, there are positive returns of two longshort profitability portfolios, while the market-adjusted returns on their long-only portfolios are significantly positive.

I now examine the long-only FW strategies and the long-short VW strategies as representative strategies in the remainder of this paper. The reasons are as follows. On the whole, each of the long-only FW strategies and the long-short VW strategies outperforms the long-only VW strategies and the long-short FW strategies. A number of recent smart beta ETFs take the forms of the long-only FW portfolio. General longshort portfolios for factor investing such as the Fama-French three factors are VW. Moreover, the results from dynamic strategies using FW do not significantly differ with those using VW. To save space, I do not report all the findings.

7) I do not identify the better investment methodology between long-only and long-short approaches here despite I recognize the difference of return-risk profiles of styles between two approaches. The average return on the long-short portfolio is the long-side portfolio return minus the short-side portfolio return, while the average return on the long-only portfolio is the raw return on the long-side portfolio in this paper. Thus, the performance of the long-only approach depends on benchmarks. Without benchmarks, long-only approaches outperforms long-short approaches whenever returns on short-side portfolios are positive. When market returns are used as the benchmarks for the long-only approaches, long-short approaches outperforms long-only approaches if short-side portfolio returns are lower than market returns, which usually occurs in many markets. Additionally, Blitz et al. (2014) uses the risk-free rate as the benchmark. As the superiority between two approaches may vary with benchmarks for long-only approaches, I do not directly present the outperforming approach. Instead, average raw returns, excess returns, and market-adjusted returns are reported in $<$ Table $2>$ to reveal performance differences among the styles from two approaches.

8) Kho (1997) shows that Korean stocks from 1980 to 1995 have insignificant negative momentum profits in months, and Chae and Eom (2009) note that they have weak negative momentum profits in months from 1980 to 2005 . 


\section{〈Table 3〉 Correlations}

This table shows the correlation coefficients across the KOSPI index, and the long-only FW and the long-short VW portfolios for nine styles. The sample period is from July 1987 to June 2017.

\begin{tabular}{|c|c|c|c|c|c|c|c|c|c|c|c|c|c|c|c|c|c|c|c|}
\hline & & \multirow[b]{2}{*}{$\begin{array}{l}\text { KOSPI } \\
\text { index }\end{array}$} & \multicolumn{9}{|c|}{ Long-only FW portfolios } & \multicolumn{8}{|c|}{ Long-short VW portfolios } \\
\hline & & & Size & value & $\begin{array}{l}\text { Mom- } \\
\text { entum }\end{array}$ & $\begin{array}{c}\text { Low } \\
\text { vola- } \\
\text { tility }\end{array}$ & $\begin{array}{l}\text { Low } \\
\text { beta }\end{array}$ & $\begin{array}{l}\text { Profit- } \\
\text { ability }\end{array}$ & $\begin{array}{c}\text { Invest- } \\
\text { ment }\end{array}$ & Quality & $\begin{array}{l}\text { Divi- } \\
\text { dend }\end{array}$ & Size & value & $\begin{array}{l}\text { Mom- } \\
\text { entum }\end{array}$ & $\begin{array}{c}\text { Low } \\
\text { Vola- } \\
\text { tility }\end{array}$ & $\begin{array}{l}\text { Low } \\
\text { beta }\end{array}$ & $\begin{array}{l}\text { Profit- } \\
\text { ability }\end{array}$ & $\begin{array}{c}\text { Invest- } \\
\text { ment }\end{array}$ & Quality $\begin{array}{l}\text { Divi- } \\
\text { dend }\end{array}$ \\
\hline & $\begin{array}{r}\text { KOSPI } \\
\text { index }\end{array}$ & 1.000 & & & & & & & & & & & & & & & & & \\
\hline Long- & Size & 0.702 & 1.000 & & & & & & & & & & & & & & & & \\
\hline only & value & 0.778 & 0.941 & 1.000 & & & & & & & & & & & & & & & \\
\hline \multirow{7}{*}{$\begin{array}{l}\text { FW } \\
\text { portfolios }\end{array}$} & Momentum & 0.792 & 0.886 & 0.873 & 1.000 & & & & & & & & & & & & & & \\
\hline & Low volatility & 0.782 & 0.864 & 0.890 & 0.883 & 1.000 & & & & & & & & & & & & & \\
\hline & Low beta & 0.723 & 0.936 & 0.931 & 0.882 & 0.934 & 1.000 & & & & & & & & & & & & \\
\hline & Profitability & 0.809 & 0.910 & 0.916 & 0.937 & 0.953 & 0.939 & 1.000 & & & & & & & & & & & \\
\hline & Investment & 0.798 & 0.964 & 0.954 & 0.918 & 0.890 & 0.923 & 0.933 & 1.000 & & & & & & & & & & \\
\hline & Quality & 0.806 & 0.949 & 0.942 & 0.935 & 0.929 & 0.937 & 0.966 & 0.979 & 1.000 & & & & & & & & & \\
\hline & Dividend & 0.786 & 0.918 & 0.938 & 0.898 & 0.934 & 0.909 & 0.958 & 0.936 & 0.958 & 1.000 & & & & & & & & \\
\hline Long- & Size & -0.198 & 0.488 & 0.340 & 0.296 & 0.246 & 0.379 & 0.285 & 0.347 & 0.330 & 0.327 & 1.000 & & & & & & & \\
\hline short & value & 0.124 & 0.224 & 0.400 & 0.205 & 0.296 & 0.262 & 0.256 & 0.248 & 0.260 & 0.333 & 0.200 & 1.000 & & & & & & \\
\hline & Momentum & -0.050 & -0.244 & -0.240 & 0.084 & -0.062 & -0.152 & -0.059 & -0.208 & -0.128 & -0.122 & -0.158 & -0.073 & 1.000 & & & & & \\
\hline \multirow[t]{6}{*}{ portfolios } & Low volatility & -0.339 & -0.535 & -0.457 & -0.486 & -0.229 & -0.364 & -0.377 & -0.522 & -0.443 & -0.385 & -0.374 & 0.033 & 0.159 & 1.000 & & & & \\
\hline & Low beta & -0.529 & -0.363 & -0.345 & -0.408 & -0.218 & -0.165 & -0.301 & -0.424 & -0.363 & -0.348 & 0.161 & 0.031 & 0.081 & 0.537 & 1.000 & & & \\
\hline & Profitability & -0.224 & -0.467 & -0.417 & -0.330 & -0.180 & -0.289 & -0.217 & -0.452 & -0.348 & -0.289 & -0.406 & -0.111 & 0.393 & 0.658 & 0.413 & 1.000 & & \\
\hline & Investment & -0.077 & 0.021 & 0.037 & 0.018 & -0.018 & -0.011 & -0.029 & 0.097 & 0.074 & -0.013 & 0.157 & 0.206 & -0.149 & 0.020 & 0.058 & -0.210 & 1.000 & \\
\hline & Quality & -0.322 & -0.406 & -0.365 & -0.372 & -0.298 & -0.351 & -0.349 & -0.370 & -0.304 & -0.345 & -0.147 & 0.019 & 0.108 & 0.421 & 0.308 & 0.353 & 0.554 & 1.000 \\
\hline & Dividend & -0.146 & -0.200 & -0.119 & -0.144 & 0.049 & -0.066 & -0.006 & -0.189 & -0.092 & 0.060 & -0.102 & 0.264 & 0.267 & 0.499 & 0.355 & 0.614 & -0.105 & 0.2481 .000 \\
\hline
\end{tabular}


$<$ Table $3>$ presents the correlation coefficients across KOSPI index and the longonly FW and the long-short VW portfolios for nine styles. While all of the long-only FW portfolios are positively correlated with market returns of $0.702 \sim 0.809$, almost all long-short VW portfolios are negatively correlated with market returns of -0.529 to -0.050, except value style of 0.124 . This relationship supports literature such as Ilmanen and Kizer (2012) and Blitz et al. (2014), who argues that the long-only approach for factor investing correlates with the market more whereas the long-short approach facilitates effective factor diversification, as they remove much of the market exposure through offsetting short positions.

Even for the equivalent style, the long-only FW portfolios are weakly correlated with the long-short VW portfolios from 0.488 of size through - 0.304 of quality, while the correlations of between long-only FW and VW portfolios of the same style are above 0.93 . These results confirm the difference between the portfolios from the top stocks with desired characteristic and the portfolios from style spread. Correlation coefficients across the long-only FW styles are relatively high, from 0.864 (size and low volatility) to 0.979 (investment and quality), implying that the long-only FW portfolios fail to independently represent exposure to the intended factors or to capture pure factor premiums again. For instance, quality and profitability highly correlate with other styles, on average 0.949 and 0.939 . These style portfolios hold many stocks involved in other styles. In contrast, styles weakly correlate across the long-short VW portfolios from -0.406 (size and profitability) to 0.658 (low volatility and profitability). 10 of 36 pairwise correlations are negative, and 32 of 36 pairwise correlations are less than 0.5. Hence, long-short portfolios enable providing the exposure to the intended factors more and effective factor diversification.

The above results of high correlation across the long-only FW styles and between the long-only FW styles and market imply that many equal securities overlap in different long-only FW portfolios. Thus, I analyze whether the long-only FW portfolios provide with the intended factor exposure. Following multivariate factor regressions of excess returns of the long-only FW style portfolios on excess returns of market and various factors are used for the examination.

$$
\begin{gathered}
R_{i t}-R_{f t}=\alpha_{i}+\beta_{i}\left(R_{m t}-R_{f t}\right)+s_{i} S M B_{t}+h_{i} H M L_{t}+\varepsilon_{i t} \\
R_{i t}-R_{f t}=\alpha_{i}+\beta_{i}\left(R_{m t}-R_{f t}\right)+s_{i} S M B_{t}+h_{i} H M L_{t}+r_{i} R M W_{t}+c_{i} C M A_{t}+m_{i} M O M_{t}+\varepsilon_{i t}
\end{gathered}
$$

where $R_{i t}$ is the return on the long-only $\mathrm{FW}$ portfolio for style $i$ in month $t, R_{f t}$ is risk-free rate (MSB) in month $t, R_{m t}$ is the return on the market (KOSPI index) in month $t, S M B_{t}, H M L_{t}, R M W_{t}, C M A_{t}$, and $M O M_{t}$ are the returns for the factor-mimicking 
portfolios related to size, value, profitability, investment, and momentum in month $t$, $\alpha_{i}, \beta_{i}, s_{i}, h_{i}, r_{i}, c_{i}$, and $m_{i}$ are the factor coefficients to be estimated for style $i$, and $\varepsilon_{i t}$ is the residual for style $i$ in month $t$. Factor-mimicking portfolios, $S M B_{t}, H M L_{t}$, $R M W_{t}, C M A_{t}$, and $M O M_{t}$, are long top $30 \%$ and short bottom $30 \%$ of stocks sorted on factor characteristic and rebalanced monthly, which are the long-only VW portfolios in this study, in effect. Equation (4) is the classical Fama-French three-factor model, and equation (5) is the Fama and French (2015) five-factor model added the momentum factor. I also examine the Carhart (1997) four-factor model and the Fama-French five-factor model, and the findings are not significantly different with results from equations (4) and (5).

$<$ Table $4>$ presents results of multivariate factor regressions. The evidence reveals that all long-only FW portfolios load positively and significantly on market and size factor, hence, they capture common variation in style returns. For value factor, while significance of value factor coefficients for size, momentum, and investment portfolios are low, suggesting that they tend to hold lower book-to-market-ratio stocks, the dividend portfolio have high loading on value factor, suggesting that they provide meaningful value exposure. Most of long-only FW portfolios present either insignificant or significant negative exposures to the momentum factor, with the exception of momentum portfolios itself. This means that majority of outperforming style involve stocks which were not winners over past 1 year. Low volatility and low beta load significantly and highly on profitability factor, in especial, profitability factor loading of low volatility are similar with that of profitability portfolios itself. Note that low volatility and profitability have the highest correlation across the long-short VW portfolios. Therefore, low volatility strategy may also capture profitability premium. In summary, long-only FW portfolios seem to provide several factor exposure. It can be the chance to obtain various style sources to outperform, but, the benefit from exposure to one factor can be often cancelled out by the loss attributed to the exposure to another (Glushkov, 2015).

Since the outperformance of styles is not stable over time and different styles demonstrate disparate time-varying performance, I investigate style performances in six five-year subperiods. <Table $5>$ shows three of the best performers and three of the worst performers among various strategies of style investment in the subperiods. According to <Table 5>, return rankings across styles vary with the subperiods. Although value is the best in the three subperiods in the long-only FW strategy, it is the worst during July 2007 June 2012. Size, low beta, and low volatility are also placed in the best or the worst performers depending on the time and the weighting scheme. Additionally, two long-short profitability portfolios do not have significant profits during 


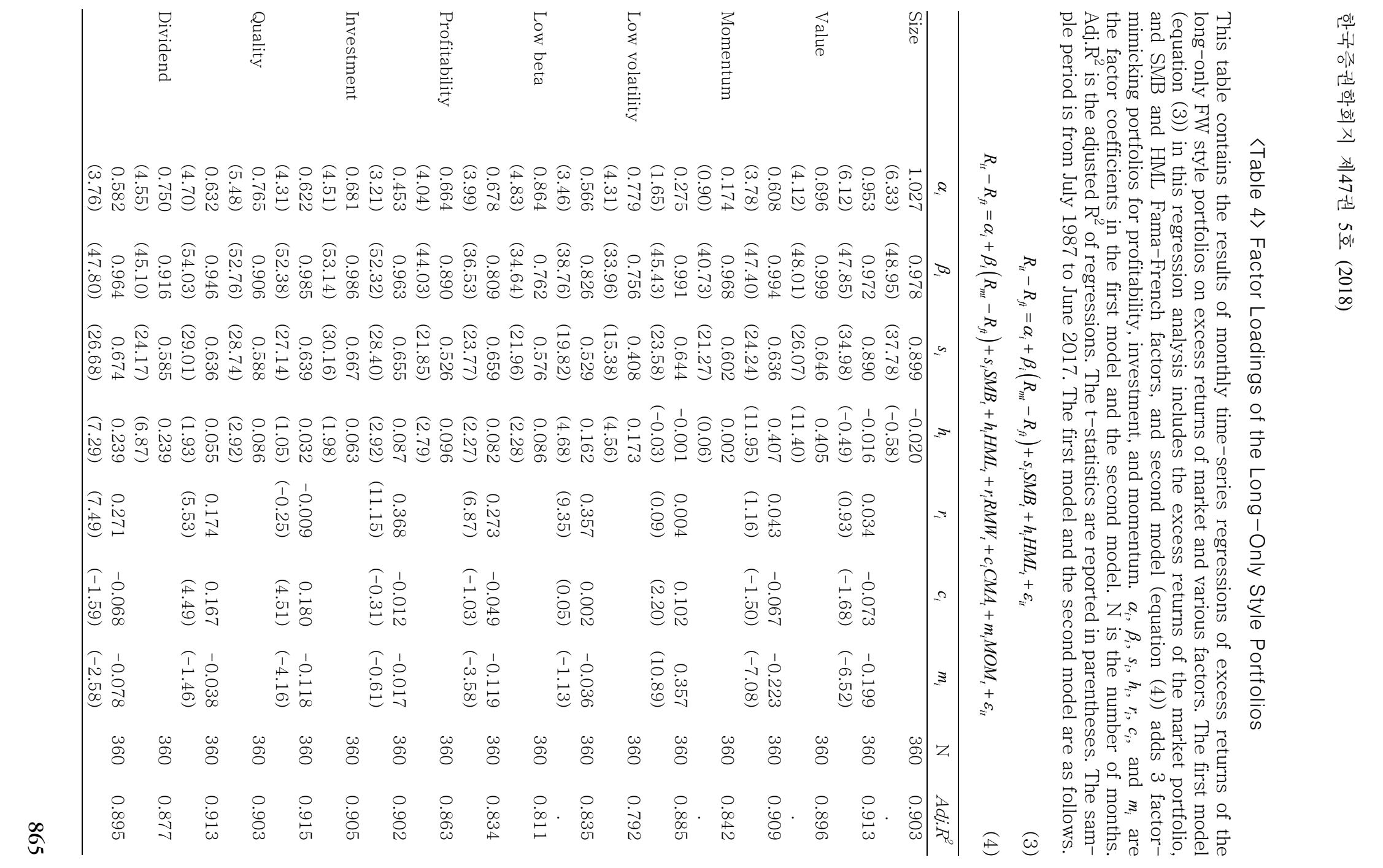


This table shows three of the best performers and three of the worst performers in various strategies of style investment, their average returns $(\%)$, and returns on the KOSPI index in the equivalent subperiods. Panels A and B present the best and the worst among long-only and long-short portfolios. FW is fundamental-weighted portfolios, and VW is value-weighted portfolios. The sample period is from July 1987 to June 2017.

\begin{tabular}{|c|c|c|c|c|c|c|c|c|c|c|c|c|c|}
\hline & & \multicolumn{2}{|c|}{ 1987. $7 \sim 1992.6$} & \multicolumn{2}{|c|}{ 1992. 7 1997. 6} & \multicolumn{2}{|c|}{ 1997. 7 2002. 6} & \multicolumn{2}{|c|}{ 2002. 7 2007. 6} & \multicolumn{2}{|c|}{ 2007. 7 2012. 6} & \multicolumn{2}{|c|}{ 2012. 7 2017. 6} \\
\hline & & Style & Mean & Style & Mean & Style & Mean & Style & Mean & Style & Mean & Style & Mean \\
\hline \multicolumn{14}{|c|}{ Panel A: Long-only portfolios } \\
\hline \multirow[t]{6}{*}{ FW } & Top1 & Value & 1.414 & Size & 2.922 & Value & 2.293 & Value & 3.671 & Dividend & 1.524 & Size & 1.871 \\
\hline & Top2 & Dividend & 1.289 & Low beta & 2.465 & Low beta & 2.164 & Dividend & 3.491 & Size & 1.485 & Low volatility & 1.741 \\
\hline & Top3 & Quality & 1.285 & Value & 2.309 & Size & 2.064 & Low volatility & 3.220 & Low volatility & 1.469 & Value & 1.675 \\
\hline & Bottom3 & Size & 0.913 & Profitability & 2.128 & Dividend & 1.506 & Quality & 2.862 & Momentum & 1.093 & Investment & 1.423 \\
\hline & Bottom2 & Low volatility & 0.849 & Low volatility & 1.981 & Investment & 1.341 & Momentum & 2.808 & Low beta & 1.075 & Profitability & 1.353 \\
\hline & Bottom1 & Low beta & 0.767 & Momentum & 1.004 & Momentum & -0.268 & Profitability & 2.775 & Value & 1.034 & Momentum & 1.294 \\
\hline \multirow[t]{6}{*}{ VW } & Top1 & Value & 1.217 & Size & 2.278 & Profitability & 1.788 & Dividend & 3.337 & Low volatility & 1.641 & Value & 1.467 \\
\hline & Top2 & Quality & 1.094 & Low beta & 2.197 & Quality & 1.561 & Value & 3.330 & Value & 1.638 & Low volatility & 1.357 \\
\hline & Top3 & Dividend & 1.016 & Profitability & 2.162 & Low volatility & 1.321 & Momentum & 2.651 & Dividend & 1.260 & Dividend & 1.332 \\
\hline & Bottom3 & Low volatility & 0.719 & Value & 1.817 & Low beta & 0.702 & Quality & 2.337 & Investment & 1.077 & Profitability & 1.115 \\
\hline & Bottom2 & Profitability & 0.697 & Investment & 1.718 & Size & 0.458 & Low beta & 2.333 & Quality & 0.932 & Momentum & 0.920 \\
\hline & Bottom1 & Low beta & 0.570 & Momentum & 1.064 & Momentum & -0.200 & Size & 2.281 & Low beta & 0.629 & Investment & 0.718 \\
\hline \multicolumn{2}{|c|}{ KOSPI index } & & 0.895 & & 0.601 & & 0.583 & & 1.672 & & 0.794 & & 0.564 \\
\hline \multicolumn{14}{|c|}{ Panel B: Long-short portfolios } \\
\hline \multirow[t]{6}{*}{ FW } & Top1 & Dividend & 1.145 & Size & 1.599 & Low beta & 2.180 & Value & 1.350 & Low volatility & 0.914 & Size & 0.922 \\
\hline & Top2 & Quality & 1.051 & Low beta & 0.720 & Value & 1.495 & Low volatility & 0.924 & Dividend & 0.560 & Value & 0.915 \\
\hline & Top3 & Value & 1.042 & Value & 0.163 & Size & 1.437 & Dividend & 0.864 & Size & 0.537 & Low volatility & 0.817 \\
\hline & Bottom3 & Profitability & 0.147 & Profitability & -0.007 & Profitability & 0.741 & Investment & 0.229 & Momentum & 0.284 & Profitability & 0.150 \\
\hline & Bottom2 & Low volatility & -0.070 & Low volatility & -0.461 & Dividend & 0.046 & Size & 0.128 & Profitability & 0.140 & Investment & 0.072 \\
\hline & Bottom1 & Low beta & -0.019 & Momentum & -2.078 & Momentum & -2.441 & Quality & -0.092 & Low beta & 0.095 & Momentum & -0.098 \\
\hline \multirow[t]{6}{*}{ VW } & Top1 & Value & 0.996 & Size & 0.768 & Low volatility & 2.563 & Dividend & 1.789 & Value & 1.191 & Value & 1.568 \\
\hline & Top2 & Quality & 0.823 & Profitability & 0.430 & Profitability & 1.866 & Value & 1.727 & Low volatility & 1.138 & Low volatility & 1.446 \\
\hline & Top3 & Dividend & 0.775 & Quality & 0.409 & Quality & 1.762 & Momentum & 0.624 & Dividend & 0.459 & Quality & 0.774 \\
\hline & Bottom3 & Profitability & -0.078 & Investment & 0.027 & Value & 0.515 & Quality & 0.307 & Profitability & 0.0004 & Profitability & 0.298 \\
\hline & Bottom2 & Low beta & -0.110 & Value & -0.344 & Size & -1.121 & Investment & 0.223 & Quality & -0.0004 & Momentum & -0.017 \\
\hline & Bottom1 & Low volatility & -0.280 & Momentum & -1.815 & Momentum & -1.928 & Low beta & 0.079 & Low beta & -0.461 & Investment & -0.061 \\
\hline
\end{tabular}


the entire period and are losers in many subperiods; however, long-short VW portfolios for profitability are the second winner from July 1992 June 2002. Comparing Panels A and B, return rankings are mostly similar between long-only and long-short portfolios, yet they are not completely equal. Especially, the three worst styles in long-only portfolios are often different from those in long-short portfolios due to the distinction between the elimination and non-elimination of undesired characteristics for the style. As a result, time-varying style rankings support that dynamic style allocations can produce superior or stable profits.

\section{Regime-switching Model}

\subsection{Estimation of the Model}

To identify style regimes, I use the classical Markov-switching model (MSM) introduced by Hamilton (1989). A given time series $y_{t}$ representing the style regime is assumed to have a regime-dependent distribution. With the state variable indicating the regimes in time $t, s t$, and $y_{t}$ normally distributed with a regime-dependent mean value, $\mu_{s_{t}}$, and a regime-dependent volatility, $\sigma_{s_{t}}$, is as follows:

$$
y_{t}=\mu_{s_{t}}+\sigma_{s_{t}} \epsilon_{t}
$$

where $\epsilon_{t} \sim$ i.i.d $N(0,1)$. As three style regimes are assumed, $s_{t} \in\{1,2,3\}$ is assumed to follow a homogenous first-order Markov chain with transition probabilities, P. ${ }^{9}$

$$
\mathbf{P}=\left[\begin{array}{lll}
p_{11} & p_{12} & p_{13} \\
p_{21} & p_{22} & p_{23} \\
p_{31} & p_{32} & p_{33}
\end{array}\right]
$$

where $p_{i j}=\operatorname{pr}\left(s_{t}=j \mid s_{t-1}=i\right)$, that is, the unobservable state variable $s_{t}$ is determined only by $s_{t-1}$. For example, since $p_{13}$ is calculated as $\left(1-p_{11}-p_{12}\right)$ under the assumption of three regimes, all transition probabilities can be calculated with estimation of six transition probabilities. Therefore, following 12 parameters, $\theta$, are estimated under the three regime MSM.

9) Most of literature such as Ang and Bekaert (2002, 2004), Kritzman et al. (2012), Hammerschmid and Lohre (2014) assumes two regime in the MSMs. In this case, two regimes of stock markets are usually identified as the event regime with the volatile price movement and the normal regime, further, if an extreme abnormal event is identified as one regime, other events would be identified as another regime even though they have different distributions. Therefore, I assume three regimes that can capture an event situation and other two states with different distributions. Assuming four regimes is rejected because I recognize that these three regimes are sufficient to classify the style return-risk profiles. For instance, as same style is the best winner in two normal regimes in some estimation results of MSMs, I judge that it is not needed to separate more regimes. Also, transaction costs may increase from more style rotations under four regimes. 


$$
\theta=\left\{\mu_{1}, \mu_{2}, \mu_{3}, \sigma_{1}, \sigma_{2}, \sigma_{3}, p_{11}, p_{12}, p_{21}, p_{22}, p_{32}, p_{33}\right\}
$$

The parameters of regime-switching models can be estimated by maximum likelihood function of $y_{t}$. I estimate MLE (maximum likelihood estimates) based on numerical optimization method and EM algorithm (expectation maximization algorithm). In the process to estimate MLE through EM algorithm, probabilities are needed to obtain the expectation of state variables. I use a smoothed probability and a recursive filtered probability. The smoothed probability is ex-post probability belonging to state $i$ in time $t$, that is, $\operatorname{Pr}\left(s_{t}=i \mid y_{1}, \ldots, y_{T} ; \theta\right)$. The recursive filtered probability is ex-ante probability belonging to state $i$ in time, which is newly calculated at every time $t$, with all information until time $t$, that is, $\operatorname{Pr}\left(s_{t}=i \mid y_{1}, \ldots, y_{t}\right)$.

The choice of $y_{t}$ identifying style regimes is very important. $y_{t}$ has to reflect the time-varying risk-return profile of style premium. In general, many studies such as Ang and Bekaert $(2002,2004)$ use stock market returns as $y_{t}$ for asset allocations. Literature including Lucas et al. (2002), Arshanapalli et al. (2004), Beckers and Thomas (2010), Vliet and Blitz (2011), and Hammerschmid and Lohre (2014) report that the time variation of style premium is related to the business cycle and that macroeconomic variables such as inflation change, GNP, economic growth rate, etc., can be used to estimate the MSM for the style allocation. Lucas et al. (2002) argue that business cycle oriented approaches exhibit the best overall performance in the US market. Arshanapalli et al. (2004) show high relationship between style premiums and macroeconomic variables in international markets. Lakonishok et al. (1994), Copeland and Copeland (1999), Beckers and Thomas (2010), Naes et al. (2011), Vliet and Blitz (2011), and Asness et al. (2013) also document that the style risk-return profile is closely connected with business cycle. Therefore, I use the time series of macroeconomic variables such as stock market returns (KOSPI index return), coincident composite index (CCI) growth rate, leading composite index (LCI) growth rate, and GDP growth rate to capture the state of style risk-return profile and to identify regimes. ${ }^{10}$ )

The GDP growth rate is measured as the quarter-over-quarter percentage growth in seasonally adjusted Korea real GDP. GDP is only measured each quarter, while all

10) Composite Economic Indexes that Statistics Korea provide to examine and predict the business cycle and overall economic activities, such as production, consumption, employment, finance, trade, and investment, comprise coincident composite index (CCI), leading composite index (LCI), and lagging composite index. In this paper, CCI and LCI are used to identify economic regimes in Korean market. CCI comprises the seven indices of industrial production, services, value of construction completed, retail sales, nonagricultural employment size, domestic shipment, and Imports, and LCI comprises the nine indices of inventory cycle indicator, consumer expectation, value of construction orders received, domestic machinery shipment, export and import price, international commodity prices, jobs rate, KOSPI, and term spread. 
other variables are available on a monthly frequency. Thus, GDP regimes can have a chance to switch quarterly unlike regimes from all other variables.

\subsection{Estimation Results}

$<$ Table 6> gives the results of the three-state MSMs fitted separately to each of the four underlying variables, KOSPI index return, CCI growth rate, LCI growth rate, and the GDP growth rate for the sample period of July 1985 to June 2017. The regimes are clearly identified by the volatilities and means of the underlying series, and I can characterize regime 2 as a high volatility state, regime 1 as a low volatility state, and regime 3 as a high mean state. Regime 2 s from the macroeconomic variables have the highest volatility and the lowest mean (the GDP growth rate and CCI growth rate) or intermediate mean (KOSPI index return and LCI growth rate), representing a recession. Excluding regime 2, regime 1 and regime 3 represent normal phases, low-mean/low-volatility state and high-mean/high-volatility state. Transition probabilities of $p_{11}$ and $p_{33}$ from all macroeconomic variables show their high persistence from $0.926 \sim 0.992$. Further, the persistence in the normal regimes ( 1 and 3) are longer than in the recession regime. In fact, thi high persistence is one of representative characteristics of MSMs. Ang and Bekaert (2002, 2004), Guidolin and Timmermann (2008), Kritzman et al. (2012), Hammerschmid and Lohre (2014) also report larger transition probabilities for $p_{i i}$ than 0.9 .

For dynamic style allocation strategies based on regime switching, it is needed to grasp the current regime (or state). As smoothed probabilities and recursive filtered probabilities in time $t$ are calculated in the process of estimating MSMs, <Figure 1> plots each variable's historical state probabilities of being in each regime over time. According to the figures, all variables' state probabilities do not perfectly coincide. Nevertheless, all macroeconomic variables that state probabilities of being in regime 2 of the recession are very high in Korea's economic crisis that started from the last few months of 1997 and the global financial crisis in 2008; regime 1 of the lowmean/low-volatility normal state includes recent years from 2011; and regime 3 of the high-mean/high-volatility normal state includes periods before Korea's economic crisis. This division of regimes with low regime transition may be caused by significant stronger distribution of low-mean/low-volatility in recent years than before. ${ }^{11}$ )

11) Identification of regimes may vary by sample periods. If only recent data are used, regimes more frequently shift as the past high mean-high volatility state is eliminated. It is caused by assumption of regimes with relative difference of distributions. 
Therefore, the regime-switching model is useful to pinpoint distinguishing periods such as the economic/financial crisis or booming economic cycle (Hammerschmid and Lohre, 2014). In particular, I assume that the three regimes facilitate separating the event state (such as regime 2) from the normal state and further decompose the two regimes in the normal state. Under the assumption of two regimes, identifying the state may be limited to one extreme event state and one normal state.

\section{〈Table 6〉 Estimated parameters from Three-Regime MSM}

This table presents parameters estimated for three regimes by Markov switching models (MSMs), using the KOSPI index return, the CCI growth rate, the LCI growth rate, and the GDP growth rate for the sample period of July 1985 to June 2017. The standard errors are reported in parentheses.

\begin{tabular}{|c|c|c|c|c|c|c|}
\hline & & \multirow[b]{2}{*}{ Mean $(\%)$} & \multirow{2}{*}{$\begin{array}{l}\text { STD } \\
(\%)\end{array}$} & \multicolumn{3}{|c|}{ Transition probabilities } \\
\hline & & & & $\begin{array}{l}\text { Regime } 1 \\
(\mathrm{t}-1)\end{array}$ & $\begin{array}{c}\text { Regime } 2 \\
(\mathrm{t}-1)\end{array}$ & $\begin{array}{c}\text { Regime } 3 \\
(t-1)\end{array}$ \\
\hline \multirow[t]{6}{*}{ KOSPI index return } & Regime 1(t) & 0.417 & 2.596 & 0.992 & 0.000 & 0.006 \\
\hline & & $(0.311)$ & (1.233) & $(0.005)$ & $(0.00)$ & \\
\hline & Regime $2(\mathrm{t})$ & 0.778 & 15.000 & 0.000 & 0.975 & 0.004 \\
\hline & & $(2.464)$ & $(47.833)$ & $(0.000)$ & $(0.023)$ & $(0.004)$ \\
\hline & Regime $3(\mathrm{t})$ & 1.336 & 7.115 & 0.008 & 0.025 & 0.989 \\
\hline & & $(0.450)$ & $(4.838)$ & & & $(0.007)$ \\
\hline \multirow[t]{6}{*}{ CCI growth rate } & Regime $1(\mathrm{t})$ & 0.300 & 0.247 & 0.954 & 0.138 & 0.059 \\
\hline & & $(0.021)$ & $(0.007)$ & $(0.021)$ & $(0.143)$ & \\
\hline & Regime $2(\mathrm{t})$ & -0.597 & 0.539 & 0.011 & 0.817 & 0.000 \\
\hline & & $(0.206)$ & $(0.116)$ & $(0.008)$ & $(0.113)$ & $(0.000)$ \\
\hline & Regime $3(\mathrm{t})$ & 0.805 & 0.342 & 0.035 & 0.044 & 0.941 \\
\hline & & $(0.039)$ & $(0.019)$ & & & $(0.028)$ \\
\hline \multirow[t]{6}{*}{ LCI growth rate } & Regime 1(t) & 0.301 & 0.226 & 0.983 & 0.018 & 0.012 \\
\hline & & $(0.018)$ & $(0.006)$ & $(0.011)$ & $(0.016)$ & \\
\hline & Regime $2(\mathrm{t})$ & 0.453 & 0.915 & 0.006 & 0.982 & 0.000 \\
\hline & & $(0.105)$ & $(0.139)$ & $(0.002)$ & $(0.016)$ & $(0.000)$ \\
\hline & Regime $3(\mathrm{t})$ & 0.693 & 0.281 & 0.011 & 0.000 & 0.988 \\
\hline & & $(0.024)$ & $(0.005)$ & & & $(0.009)$ \\
\hline \multirow[t]{6}{*}{ GDP growth rate } & Regime $1(\mathrm{t})$ & 0.709 & 0.230 & 0.937 & 0.000 & 0.029 \\
\hline & & (0.043) & $(0.013)$ & $(0.051)$ & $(0.006)$ & \\
\hline & Regime $2(\mathrm{t})$ & 0.531 & 3.773 & 0.042 & 0.525 & 0.045 \\
\hline & & (1.839) & (8.658) & $(0.048)$ & $(0.416)$ & $(0.042)$ \\
\hline & Regime $3(\mathrm{t})$ & 1.837 & 1.071 & 0.021 & 0.475 & 0.926 \\
\hline & & $(0.146)$ & $(0.275)$ & & & $(0.046)$ \\
\hline
\end{tabular}




\section{〈Figure 1〉 State Probabilities from the Three-Regime MSM}

This figure shows smoothed probabilities and recursive filtered probabilities calculated from the three-regime MSM using the KOSPI index return, the CCI growth rate, the LCI growth rate, and the GDP growth rate. The sample period is July 1985 to June 2017, but this figure shows results only from July 1987. Parameter estimates underlying these plots are reported in $\langle$ Table 4$\rangle$.

A: KOSPI index return
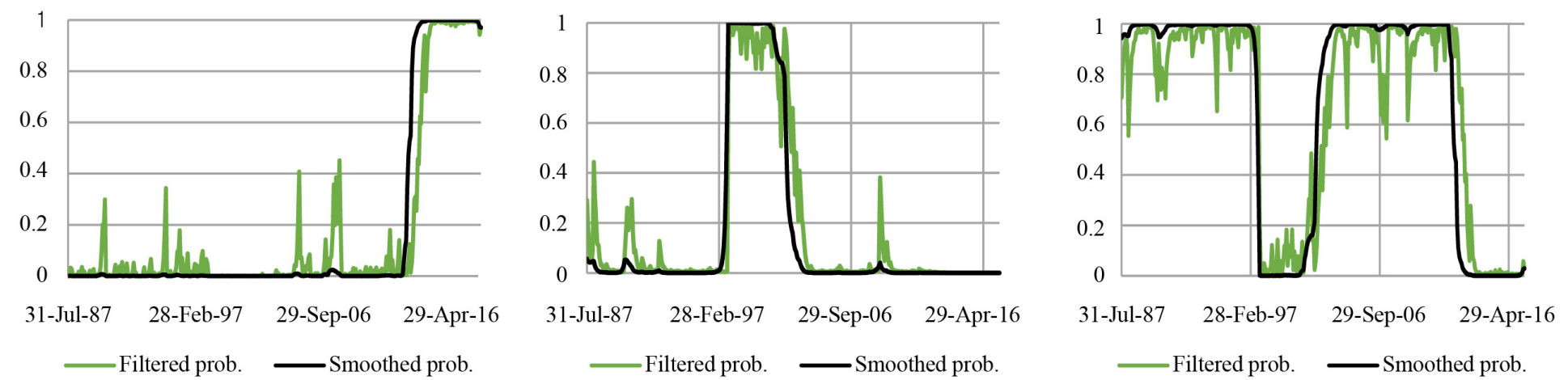

B: CCI growth rate
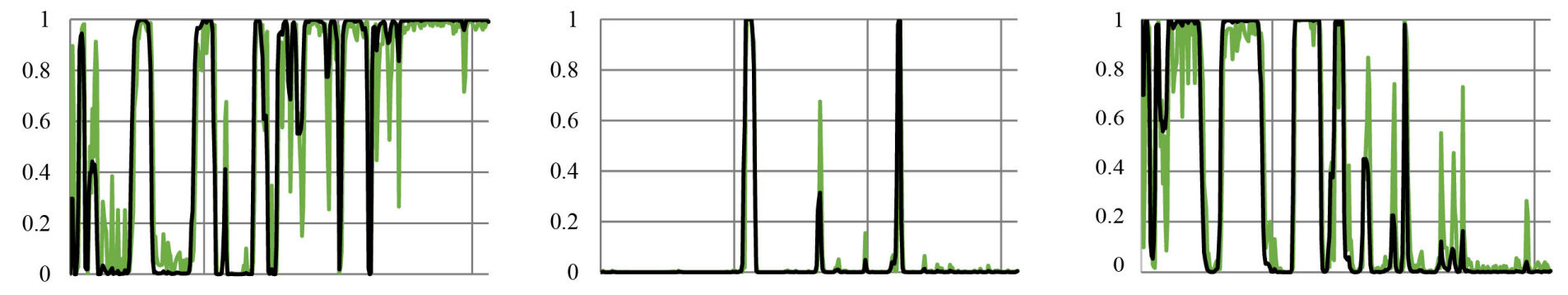

31-Jul-87 28-Feb-97 29-Sep-06 29-Apr-16

31-Jul-87 28-Feb-97 29-Sep-06 29-Apr-16

31-Jul-87 28-Feb-97 29-Sep-06 29-Apr-16

- Filtered prob. $\quad$ Smoothed prob.

- Filtered prob. $\quad$ Smoothed prob.

— Filtered prob.

Smoothed prob. 


\section{C: LCI growth rate}

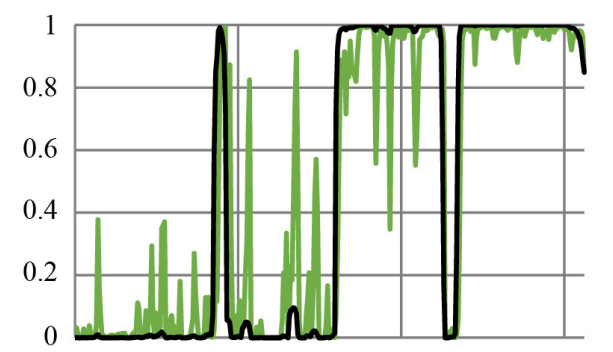

31-Jul-87 28-Feb-97 29-Sep-06 29-Apr-16 - Filtered prob. $\quad$ Smoothed prob.

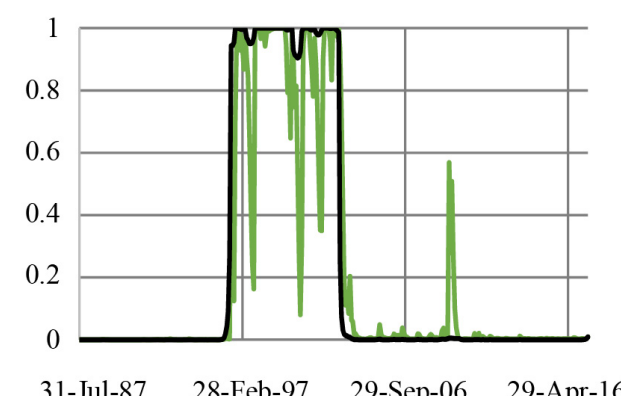

31-Jul-87 28-Feb-97 29-Sep-06 29-Apr-16 -Filtered prob. $\quad$ Smoothed prob.

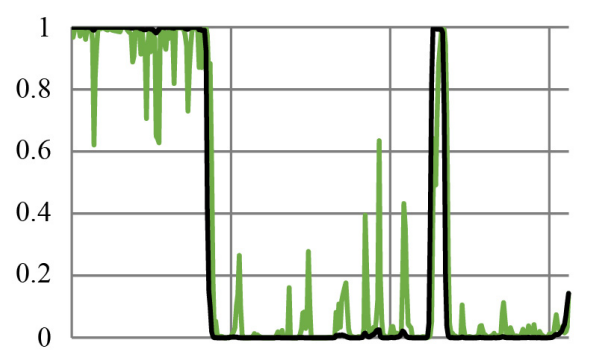

31-Jul-87 28-Feb-97 29-Sep-06 29-Apr-16 - Filtered prob. $\quad$ Smoothed prob.
D: GDP growth rate

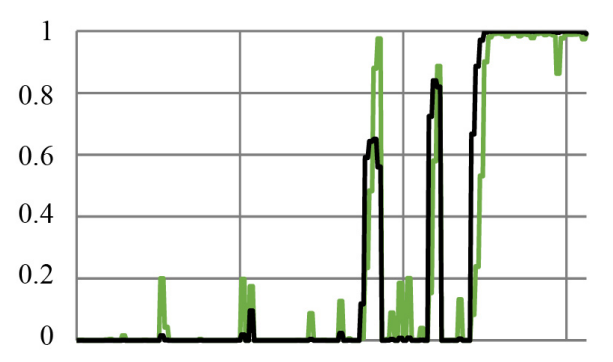

31-Jul-87 28-Feb-97 29-Sep-06 29-Apr-16 -Filtered prob. —-Smoothed prob.

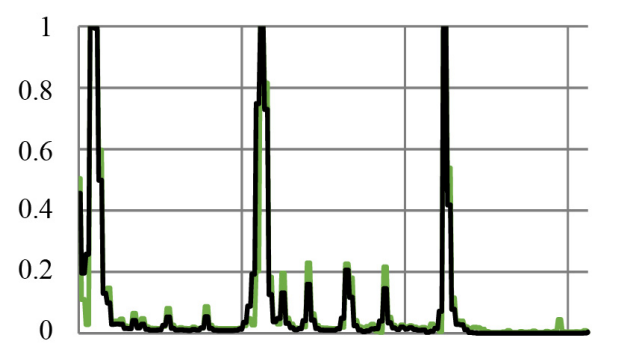

31-Jul-87 28-Feb-97 29-Sep-06 29-Apr-16 - Filtered prob. — Smoothed prob

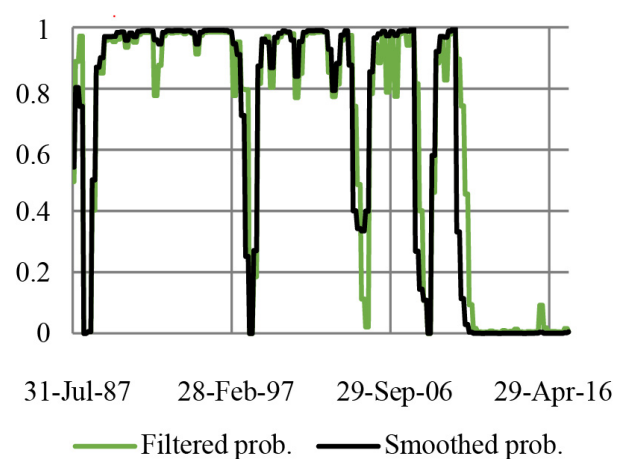




\section{Dynamic Style Allocation Strategy}

\subsection{Winners in Each Regime}

Based on the regimes identified by the four macroeconomic variables, I investigate the dynamic style allocation strategies. For the strategy, I choose the one or two winners among the styles in each regime and determine the weights of the styles in the portfolios based on the state probabilities of each regime.

$<$ Table $7>$ shows the winners and their performances in the three regimes. The winners among long-only FW portfolios are shown in Panel A of <Table $7>$. In the regime 2 of recession under the four macroeconomic variables in Panel A, value, low beta, quality, investment, size, and profitability outperform. Especially, low beta and quality are winners in regime 2 based on the two macroeconomic variables, and IR of low beta is the highest among all the winners of regime 2 . It is because low beta tilts to low market exposure during the high-market-risk and low-risk-premium period of regime 2 . In the regime 3 of the high-mean/high-volatility normal state based on the four variables, value, size, dividend, and investment generate higher returns. Value is the best performer in all of regime 3 from the four variables, and its reward-torisks is also higher than those of other styles. Size is also a winner in regime 3 based on the two variables, the GDP growth rate and the CCI growth rate. In the regime 1 of the low-mean/low-volatility normal state under the four variables, dividend, low volatility, size, and value outperform. Dividend is a winner in regime 1 based on the three variables, with high IRs. Low volatility is a winner in regime 1 based on the two variables and has the highest Sharpe ratio and IR in regime 1.

The results from long-short VW portfolios are similar to those from long-only FW portfolios, but they are not perfectly identical. According to Panel B of $<$ Table $7>$, the best performers in regime 2 under the four macroeconomic variables are low volatility, profitability, quality, size, and value. Low volatility is the winner in all of regime 2, and profitability is the winner in regime 2 based on the two variables. Similar to low beta in the long-only FW approach, low volatility including less risky stocks generates higher profits during regime 2 . In regime 3 , dividend, quality, and value outperform. Dividend and quality are the best performers in regime 3 based on the three macroeconomic variables. In regime 1 , value, low volatility, and dividend outperform. Value is the winner among long-short VW portfolios in all of regime 1, and low volatility is also the winner in regime 1 based on the three variables.

Overall, the relative performances of styles change, depending on the business cycle and the stock market condition. In the normal states (regime 1 and 3), value and dividend factors outperform. That is, except under special condition, value and 
$\langle$ Table 7〉 Performances of Two Winners in Three Regimes

This table shows performances of two winners in each of three regimes. Panels A and B present the performances of long-only FW portfolios and long-short VW portfolios for styles. The Mrk-adj. return is the market-adjusted return, which is the portfolio's monthly return minus monthly the return on the KOSPI index. The Sharpe ratio is the excess returns divided by STD, and IR is the market-adjusted returns divided by their standard deviations. The sample period is from July 1987 to June 2017.

\begin{tabular}{|c|c|c|c|c|c|c|c|c|c|c|c|c|c|}
\hline & \multirow[b]{2}{*}{ Regime } & & \multirow[b]{2}{*}{$\mathrm{N}$} & \multicolumn{6}{|c|}{ Panel A: Long-only FW portfolios } & \multicolumn{4}{|c|}{ Panel B: Long-short VW portfolios } \\
\hline & & & & Style & $\begin{array}{c}\text { Mean } \\
(\%)\end{array}$ & $\begin{array}{l}\text { STD } \\
(\%)\end{array}$ & $\begin{array}{c}\text { Mrk-adj. } \\
\text { Return } \\
(\%)\end{array}$ & $\begin{array}{c}\text { Sharpe } \\
\text { ratio }\end{array}$ & IR & Style & $\begin{array}{l}\text { Mean } \\
(\%)\end{array}$ & $\begin{array}{l}\text { STD } \\
(\%)\end{array}$ & IR \\
\hline \multirow{6}{*}{$\begin{array}{l}\text { KOSPI } \\
\text { index } \\
\text { return }\end{array}$} & 1 & Top1 & 63 & Size & 1.737 & 3.818 & 1.333 & 0.408 & 0.416 & Value & 1.592 & 3.666 & 0.434 \\
\hline & & Top2 & 63 & Low volatility & 1.619 & 2.830 & 1.214 & 0.509 & 0.504 & Low volatility & 1.532 & 4.084 & 0.375 \\
\hline & 2 & Top1 & 52 & Value & 2.304 & 17.975 & 1.464 & 0.088 & 0.130 & Low volatility & 2.439 & 9.906 & 0.246 \\
\hline & & Top2 & 52 & Low beta & 2.241 & 13.611 & 1.401 & 0.112 & 0.138 & Profitability & 2.047 & 8.795 & 0.233 \\
\hline & 3 & Top1 & 245 & Value & 2.174 & 8.244 & 1.205 & 0.171 & 0.231 & Value & 0.904 & 4.108 & 0.220 \\
\hline & & Top2 & 245 & Dividend & 2.144 & 7.608 & 1.175 & 0.181 & 0.224 & Dividend & 0.849 & 4.064 & 0.209 \\
\hline \multirow{6}{*}{$\begin{array}{l}\text { CCI } \\
\text { growth } \\
\text { rate }\end{array}$} & 1 & Top1 & 229 & Size & 2.113 & 7.616 & 1.782 & 0.218 & 0.324 & Value & 1.381 & 4.384 & 0.315 \\
\hline & & Top2 & 229 & Dividend & 2.001 & 6.641 & 1.669 & 0.233 & 0.364 & Low volatility & 1.067 & 6.328 & 0.169 \\
\hline & 2 & Top1 & 12 & Profitability & 0.935 & 22.091 & 1.797 & -0.002 & 0.274 & Profitability & 3.883 & 9.217 & 0.421 \\
\hline & & Top2 & 12 & Quality & -0.224 & 22.380 & 0.639 & -0.054 & 0.088 & Low volatility & 2.161 & 9.199 & 0.235 \\
\hline & 3 & Top1 & 119 & Value & 2.771 & 11.212 & 0.746 & 0.157 & 0.093 & Quality & 0.647 & 3.975 & 0.163 \\
\hline & & Top2 & 119 & Size & 2.322 & 10.660 & 0.297 & 0.123 & 0.034 & Dividend & 0.495 & 4.760 & 0.104 \\
\hline \multirow{6}{*}{$\begin{array}{l}\text { LCI } \\
\text { growth } \\
\text { rate }\end{array}$} & 1 & Top1 & 175 & Value & 2.030 & 6.963 & 1.222 & 0.245 & 0.295 & Value & 1.440 & 4.120 & 0.350 \\
\hline & & Top2 & 175 & Dividend & 2.020 & 5.833 & & 0.291 & 0.327 & Dividend & 1.041 & 3.687 & 0.282 \\
\hline & 2 & Top1 & 77 & Size & 2.444 & 14.965 & 2.352 & 0.113 & 0.224 & Low volatility & 1.982 & 9.096 & 0.218 \\
\hline & & Top2 & 77 & Low beta & 2.323 & 11.704 & 2.230 & 0.135 & 0.255 & Quality & 1.781 & 5.306 & 0.336 \\
\hline & 3 & Top1 & 108 & Value & 2.116 & 8.342 & 0.653 & 0.118 & 0.112 & Value & 0.615 & 3.431 & 0.179 \\
\hline & & Top2 & 108 & Investment & 2.005 & 8.176 & 0.541 & 0.106 & 0.092 & Quality & 0.480 & 3.955 & 0.121 \\
\hline \multirow{6}{*}{$\begin{array}{l}\text { GDP } \\
\text { growth } \\
\text { rate }\end{array}$} & 1 & Top1 & 103 & Dividend & 1.773 & 5.512 & 1.419 & 0.279 & 0.402 & Value & 1.533 & 4.169 & 0.368 \\
\hline & & Top2 & 103 & Low volatility & 1.761 & 4.910 & 1.406 & 0.310 & 0.448 & Low volatility & 1.468 & 4.770 & 0.308 \\
\hline & 2 & Top1 & 18 & Quality & 0.534 & 17.683 & 0.625 & -0.030 & 0.092 & Value & 0.660 & 5.815 & 0.113 \\
\hline & & Top2 & 18 & Investment & 0.417 & 17.840 & 0.508 & -0.036 & 0.058 & Low volatility & 0.388 & 8.088 & 0.048 \\
\hline & 3 & Top1 & 239 & Value & 2.407 & 10.052 & 1.271 & 0.159 & 0.189 & Dividend & 0.933 & 5.196 & 0.180 \\
\hline & & Top2 & 239 & Size & 2.350 & 9.813 & 1.213 & 0.157 & 0.160 & Quality & 0.739 & 4.358 & 0.170 \\
\hline
\end{tabular}


dividend styles tend to generate higher returns in Korean market. Performances of value are overwhelmingly the best, and value is identified as the winners in many of regimes. These results can be evidence supporting Morningstar (2017) reports that dividend, value, and low volatility are the top three smart beta attributes in order of the number of ETFs in the Korean market except for multi-factor strategies. Particularly, while the long-only value portfolios have high returns in the high-return/highvolatility regime, the spread between high and low book-to-market ratios becomes larger in the low-return/low-volatility regime during the normal state. This higher spread in a relative contraction (or recovery/slowdown) and lower spread in a expansion is consistent with Lucas et al. (2002), Zhang (2005) and Vliet and Blitz (2011). Lucas et al. (2002) document that value portfolios show higher returns in the contraction as a result from involving stocks with overly decreased prices during the and growth portfolios show higher returns in the expansion as a result from containing stocks with higher and better quality earnings expectations. This can cause the value spread to relatively increase in the contraction. Arshanapalli et al. (2004) and Vliet and Blitz (2011) argue that the growth firms have higher returns in the expansion and value firms are defensive in the contraction, and imply the higher value spread in the low-return/low-volatility regime. In the event state, low beta and low volatility representing low risk relatively produce superior returns. This confirms Gupta et al. (2014)'s findings that the MSCI World minimum volatility index is significantly defensive and outperforms following a large negative macroeconomic shock. Not surprisingly, low beta stocks with low market exposure are also defensive in a financial crisis, providing relatively high returns. Additionally, the low volatility style also generates higher returns, in the normal state with low volatility and low mean, which is linked to Gupta et al. (2014), who report that the minimum volatility index shows the large positive performance in a stagflation environment, defensively.

I sort the performances by the average returns to determine the winners in $<$ Table $7>$. The proxies for reward to risk, such as the Sharpe ratio, Sortino ratio, or IR, are also the crucial criteria for investment decisions. To save the space, winners by the reward-to-risk ratios are not reported here. The winners from the average returns quite overlap with those from the reward-to-risk ratios but are not perfectly equal. I investigate dynamic style allocations using best performers, both by the average returns and by IR in this paper, yet the results based on the winners by the average returns are mainly described.

\subsection{Performances from Dynamic Style Allocation Strategies}

Based on the previous results of style relative performances and state probabilities in each of three regimes, I construct the dynamic style allocation strategies and ana- 
lyze their performances. First, I select one or two of the styles invested in the style allocation by the return ranks in each regime and then determine the portfolio weights by the state probabilities. For comparison, as a base-case style allocation policy, I begin with analyzing static style allocations with equivalent styles used for the dynamic style allocation. Assuming that styles A, B, and C are the winners with the highest returns in regimes 1,2 , and 3 , and that styles $\mathrm{D}, \mathrm{E}$, and $\mathrm{F}$ are the second winners with the second highest returns in regimes 1,2 , and 3 , the static style allocation, denoted by SSA, is investing every month with equal weighting (i.e., 1/3) in styles A, B, and C. I also consider M-SSA, which is investing every month with equal weighting (i.e., 1/6) in styles A-F.

The performances of SSAs and M-SSAs using long-only FW portfolios based on regimes of four macroeconomic variables are reported in Panel A of <Table 8>. Overall, their results show higher returns and IRs than most of any single style (except value, size, and dividend), as well as market returns, yet the returns are not remarkably improved in other indicators. Their performances with respect to the reward-to-risk indicators are stable and placed in the middle among all of the single styles. The highest average returns in Panel A of $2.015 \%$ are from SSA of the KOSPI index return and LCI growth rate regimes, investing in value and size styles. This return is naturally lower than the return on value portfolio, $2.066 \%$, which is the best performer among single FW style portfolios in the entire sample period. SSAs of the KOSPI index and LCI growth rate have lower IRs and Sortino ratios than value's long-only FW portfolio, while they have improved performances with respect to the risk measures such as STDs, downside STDs, and the longest drawdowns. Therefore, static style allocations for the long-only FW portfolios result in stable and higher profits than the market and low-ranking styles but do not generate significant innovation compared with top styles, such as value, dividend, and low volatility.

For the long-short VW portfolios in panel B of $\langle$ Table $8>$, static style allocations improve the performances. The average returns on the SSAs except the GDP-growthrate regime are $0.915 \% \sim 0.931 \%$, which are higher than the market and almost any of the single styles of long-short VW strategies except for value (return of $0.941 \%$ ). In particular, reward-to-risk ratios of static style allocations are higher than almost any single-style portfolio. IRs of static style allocations are $0.200 \sim 0.259$, and they are higher than those of all single-style portfolios (at best 0.195). In addition, the Sortino ratio of the static style allocations is from 0.299 to 0.425 , whereas all single-style portfolios are below 0.302 . Total risk, the downside risk, and the duration of the longest drawdown of all static style allocations are smaller than all single-style portfolios. Hence, static style allocations work better for the long-short VW approach. 


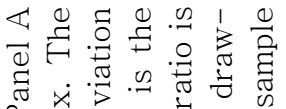

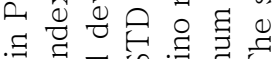

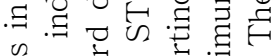

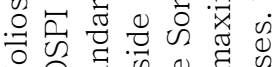

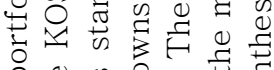
욤. 声 थ $\vec{\nabla} \overrightarrow{0}: \Xi$

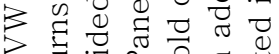

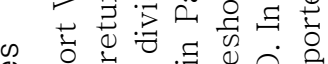
o -

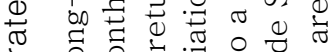

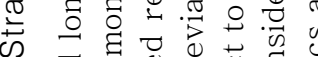

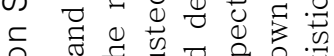

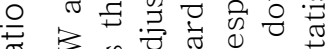
ర

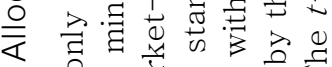

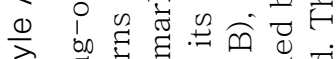

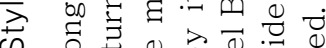

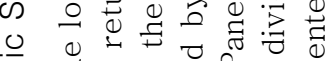

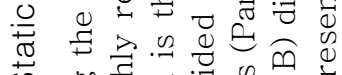

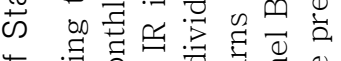

ᄂ

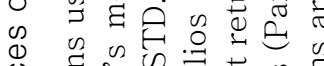

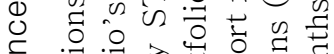

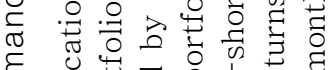
ह

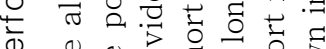

ब

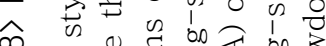

๑.

원

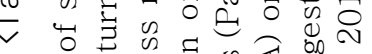

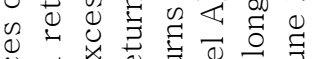

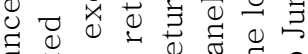

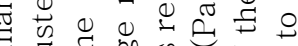

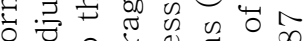
艺

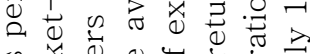

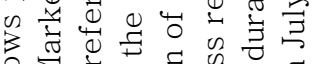
군

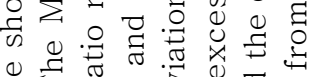

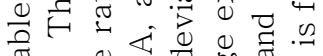

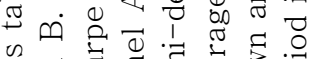

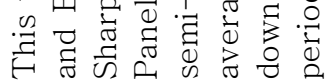

\begin{tabular}{|c|c|c|c|c|c|c|c|c|c|}
\hline & $\begin{array}{lll} & 3 \\
0 \\
0 \\
0 \\
0\end{array}$ & $\curvearrowright$ & $\stackrel{\infty}{\not+\not}$ & $\mathscr{6}$ & $\stackrel{\infty}{+}$ & 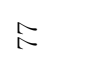 & $F$ & Is & $\stackrel{f}{F}$ \\
\hline 先 & 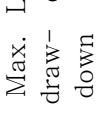 & $\begin{array}{l}\infty \\
\& \\
N \\
0 \\
i \\
i\end{array}$ & 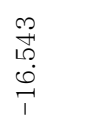 & $\begin{array}{l}0 \\
0 \\
0 \\
0 \\
1\end{array}$ & $\begin{array}{l}\infty \\
\infty \\
\infty \\
\stackrel{0}{0} \\
i\end{array}$ & \begin{tabular}{l}
$\mathscr{\&}$ \\
\multirow{N}{*}{} \\
$\stackrel{\leftrightarrow}{1}$ \\
$i$
\end{tabular} & $\begin{array}{l}\tilde{\omega} \\
\infty \\
\ddot{1}\end{array}$ & $\begin{array}{l}\mathscr{8} \\
8 \\
\dot{+} \\
\stackrel{1}{1}\end{array}$ & 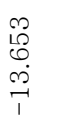 \\
\hline & 营. & 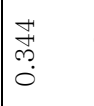 & $\begin{array}{l}\stackrel{0}{N} \\
\dddot{0} \\
\stackrel{0}{0}\end{array}$ & $\begin{array}{l}\infty \\
\stackrel{\infty}{0} \\
\stackrel{0}{0}\end{array}$ & $\begin{array}{l}\stackrel{D}{ } \\
\stackrel{2}{N} \\
0\end{array}$ & $\begin{array}{l}\underset{H}{*} \\
\stackrel{0}{0}\end{array}$ & $\stackrel{\stackrel{L}{\sim}}{\underset{0}{O}}$ & 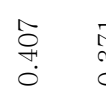 & 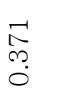 \\
\hline & 卓党 & 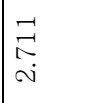 & $\begin{array}{l}\text { Nै } \\
\text { Oै } \\
\text { ì }\end{array}$ & 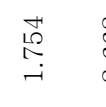 & 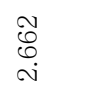 & $\overrightarrow{\vec{E}}$ & $\begin{array}{l}\stackrel{18}{8} \\
\stackrel{8}{-} \\
-1\end{array}$ & $\begin{array}{l}\stackrel{0}{H} \\
\text { N } \\
\text { in }\end{array}$ & 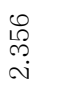 \\
\hline & & 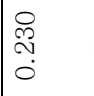 & $\begin{array}{l}2 \\
\stackrel{2}{N} \\
0\end{array}$ & $\begin{array}{l}\text { 品 } \\
\text { N } \\
0 \\
0\end{array}$ & $\begin{array}{l}\stackrel{8}{0} \\
\text { ִֻ } \\
0\end{array}$ & $\begin{array}{l}\stackrel{0}{\%} \\
\stackrel{0}{0} \\
0\end{array}$ & $\begin{array}{l}\stackrel{\circ}{\stackrel{\rho}{0}} \\
\text { ọ } \\
0\end{array}$ & $\begin{array}{l}\stackrel{0}{*} \\
\text { N. } \\
0\end{array}$ & $\begin{array}{l}0 \\
\stackrel{2}{N} \\
0 \\
0\end{array}$ \\
\hline & 是 & $\begin{array}{l}0 \\
0 \\
+1 \\
+ \\
+\end{array}$ & 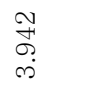 & $\begin{array}{l}\stackrel{10}{D} \\
\stackrel{5}{a} \\
i\end{array}$ & $\begin{array}{l}\infty \\
\infty \\
\infty \\
\infty\end{array}$ & $\begin{array}{l}\mathscr{0} \\
\stackrel{1}{1} \\
\stackrel{+}{+}\end{array}$ & $\begin{array}{l}\stackrel{N}{N} \\
\text { N. } \\
\end{array}$ & 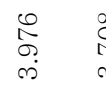 & 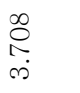 \\
\hline & $\stackrel{\mathbb{J}}{\Sigma}^{\stackrel{D}{\Sigma}}$ & 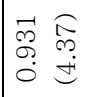 & 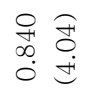 & $\begin{array}{l}\infty \\
\infty \\
\infty \\
0 \\
0 \\
0 \\
0\end{array}$ & 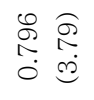 & 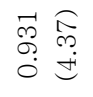 & $\begin{array}{ll}\stackrel{n}{0} & \widehat{\sigma} \\
\infty & \sigma \\
0 & \vec{J}\end{array}$ & 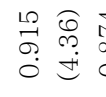 & 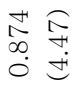 \\
\hline & 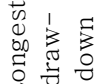 & $\infty$ & $\stackrel{\bullet}{\llcorner\Omega}$ & $\stackrel{\bullet}{\llcorner}$ & $\stackrel{\llcorner}{\llcorner}$ & $\ddot{\varnothing}$ & $\stackrel{\circ}{\llcorner}$ & $\approx$ & $\stackrel{L}{\llcorner}$ \\
\hline & 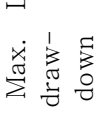 & $\begin{array}{l}\stackrel{2}{2} \\
\stackrel{9}{+} \\
\stackrel{1}{\infty} \\
\stackrel{1}{1}\end{array}$ & $\begin{array}{l}\ddot{0} \\
\stackrel{0}{i} \\
\stackrel{i}{i}\end{array}$ & $\begin{array}{l}\stackrel{8}{0} \\
\stackrel{0}{0} \\
\stackrel{0}{1} \\
1\end{array}$ & $\begin{array}{l}\mathscr{D} \\
\& \\
0 \\
0 \\
1\end{array}$ & 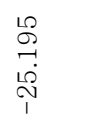 & 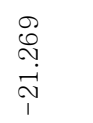 & $\begin{array}{l}\stackrel{\infty}{\sim} \\
\stackrel{\sim}{\vec{T}}\end{array}$ & 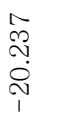 \\
\hline & 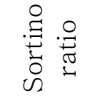 & $\begin{array}{l}\text { Ñ } \\
\text { Na } \\
0\end{array}$ & $\begin{array}{l}\stackrel{\aleph}{\dddot{O}} \\
\stackrel{0}{0}\end{array}$ & $\begin{array}{l}\vec{N} \\
\stackrel{N}{0} \\
0\end{array}$ & $\begin{array}{l}\stackrel{\vartheta}{2} \\
\stackrel{0}{0}\end{array}$ & $\begin{array}{l}\text { Ñ } \\
\text { N̦ } \\
0\end{array}$ & 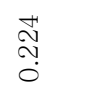 & $\begin{array}{l}\stackrel{N}{N} \\
\stackrel{N}{0}\end{array}$ & $\begin{array}{l}\stackrel{\overbrace{}}{N} \\
\text { N̦ } \\
0\end{array}$ \\
\hline & 言苟是 & $\begin{array}{l}\infty \\
\infty \\
0 \\
0 \\
0\end{array}$ & 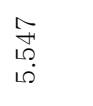 & $\begin{array}{l}\overrightarrow{0} \\
\infty \\
\infty \\
10\end{array}$ & $\begin{array}{l}\underset{N}{\infty} \\
\infty \\
i \infty\end{array}$ & $\begin{array}{l}\infty \\
0 \\
0 \\
0\end{array}$ & $\begin{array}{l}\stackrel{D}{\infty} \\
\stackrel{1}{\llcorner} \\
i \infty\end{array}$ & 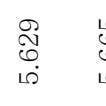 & 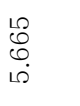 \\
\hline & 乎 & $\begin{array}{l}\mathscr{2} \\
\stackrel{2}{-} \\
0\end{array}$ & $\begin{array}{l}\text { ô. } \\
\text { ọ } \\
0\end{array}$ & $\begin{array}{l}\infty \\
\infty \\
\stackrel{-}{0}\end{array}$ & $\begin{array}{l}8 \\
\stackrel{8}{0}\end{array}$ & $\begin{array}{l}\mathscr{2} \\
\stackrel{0}{0}\end{array}$ & $\begin{array}{l}\mathscr{\Omega} \\
\stackrel{-}{0}\end{array}$ & 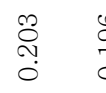 & $\begin{array}{l}\mathscr{8} \\
\stackrel{1}{0}\end{array}$ \\
\hline & 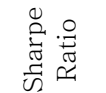 & $\begin{array}{l}\text { 贲 } \\
\stackrel{5}{0}\end{array}$ & $\begin{array}{l}\stackrel{+}{\circ} \\
\stackrel{0}{0}\end{array}$ & 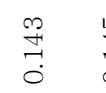 & 㝵 & $\begin{array}{l}\stackrel{\sim}{+} \\
\stackrel{-}{0}\end{array}$ & $\begin{array}{l}0 \\
\stackrel{+}{-1} \\
0\end{array}$ & $\begin{array}{l}0 \\
\stackrel{4}{*} \\
0\end{array}$ & $\begin{array}{l}\stackrel{0}{1} \\
\stackrel{-1}{0} \\
0\end{array}$ \\
\hline & 离密焉 & 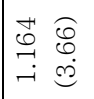 & 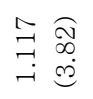 & 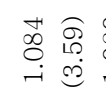 & 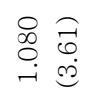 & 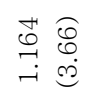 & $\begin{array}{l}8 \underset{6}{8} \\
ت \underset{6}{-0}\end{array}$ & $\begin{array}{ll}\infty & \widehat{L} \\
\infty & \infty \\
0 & \infty \\
- & \infty \\
- & 0\end{array}$ & 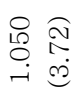 \\
\hline & 是 & 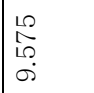 & $\begin{array}{l}\hat{N} \\
\stackrel{N}{0} \\
\infty \\
\infty\end{array}$ & $\begin{array}{l}\overrightarrow{8} \\
\infty \\
\infty\end{array}$ & $\begin{array}{l}\hat{n} \\
\infty \\
\infty\end{array}$ & 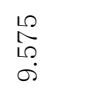 & $\begin{array}{l}8 \\
10 \\
\infty \\
\infty\end{array}$ & $\begin{array}{l}\stackrel{p}{b} \\
\stackrel{D}{\circ} \\
\infty\end{array}$ & $\begin{array}{l}\text { Th } \\
\text { Ln } \\
\infty\end{array}$ \\
\hline & 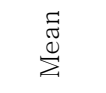 & 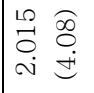 & 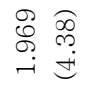 & 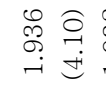 & 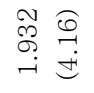 & 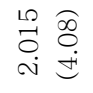 & 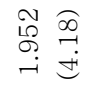 & 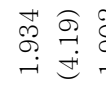 & 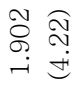 \\
\hline & & 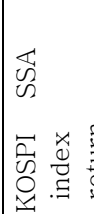 & $\begin{array}{l}\overrightarrow{1} \\
\text { w } \\
1 \\
\Sigma\end{array}$ & 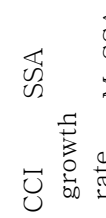 & $\begin{array}{l}\mathbb{4} \\
0 \\
0 \\
1 \\
\Sigma \\
\stackrel{0}{0}\end{array}$ & 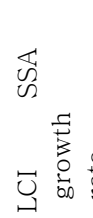 & 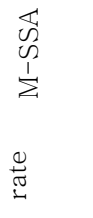 & 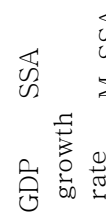 & 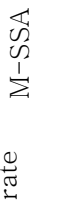 \\
\hline
\end{tabular}


Now, I investigate the dynamic style allocations. At first, I consider a style rotation, denoted by DSA1, which invests at time $t 100 \%$ in style A if regime at time $t$ - 1 is 1 , in style $\mathrm{B}$ if regime at time $t-1$ is 2 , and in style $\mathrm{C}$ if regime at time $t$ - 1 is 3 :

$$
\mathrm{DSAl}_{t}= \begin{cases}\text { Style A }: 100 \% & \text { if } \operatorname{pr}\left(s_{t-1}=1\right)>\operatorname{pr}\left(s_{t-1}=2\right) \text { and } \operatorname{pr}\left(s_{t-1}=1\right)>\operatorname{pr}\left(s_{t-1}=3\right) \\ \text { Style B }: 100 \% & \text { if } \operatorname{pr}\left(s_{t-1}=2\right)>\operatorname{pr}\left(s_{t-1}=1\right) \text { and } \operatorname{pr}\left(s_{t-1}=2\right)>\operatorname{pr}\left(s_{t-1}=3\right) \\ \text { Style C: } 100 \% & \text { if } \operatorname{pr}\left(s_{t-1}=3\right)>\operatorname{pr}\left(s_{t-1}=1\right) \text { and } \operatorname{pr}\left(s_{t-1}=3\right)>\operatorname{pr}\left(s_{t-1}=2\right)\end{cases}
$$

Next, I consider an asset allocation approach according to the state probabilities. The dynamic strategy denoted by DSA2 is investing at time $t$ in styles A, B, and C weighted by state probabilities in regimes 1,2 , and 3 at time $t$-1:

$$
\text { DSA2 }_{t}=\left\{\begin{array}{l}
\text { Style A }: \operatorname{pr}\left(s_{t-1}=1\right) \\
\text { Style B }: \operatorname{pr}\left(s_{t-1}=2\right) \\
\text { Style C }: \operatorname{pr}\left(s_{t-1}=3\right)
\end{array}\right.
$$

Also, as a simple multi-style allocation similar to DSA1 and DSA2, all of the top two styles in each regime are included for dynamic asset allocation strategies. MDSA 1 is investing at time $t 50 \%$ in style A and $50 \%$ in style D if regime at time $t-1$ is $1,50 \%$ in style $\mathrm{B}$ and $50 \%$ in style $\mathrm{E}$ if regime at time $t-1$ is 2 , and $50 \%$ in style $\mathrm{C}$ and $50 \%$ in style $\mathrm{F}$ if regime at time $t$ - 1 is 3 :

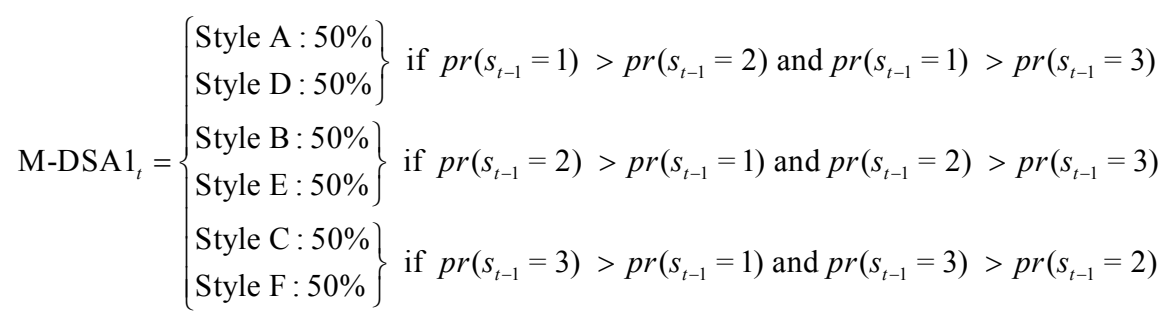

M-DSA2 is investing at time $t$ in style A and D weighted by half of the state probabilities (i.e., $0.5 \times$ probability) in regime 1 at time $t$-1, in style $\mathrm{B}$ and $\mathrm{E}$ weighted by half of the state probabilities in regime 2 at time $t$-1, and in style $\mathrm{C}$ and $\mathrm{F}$ weighted by half of the state probabilities in regime 3 at time $t$ - 1 :

$$
\text { M-DSA2 }{ }_{t}=\left\{\begin{array}{l}
\text { Style A, Style D: } p r\left(s_{t-1}=1\right) / 2 \\
\text { Style B, Style E: } \operatorname{pr}\left(s_{t-1}=2\right) / 2 \\
\text { Style C, Style F }: \operatorname{pr}\left(s_{t-1}=3\right) / 2
\end{array}\right.
$$

These four strategies may be the simplest dynamic style allocations constructed using estimated state probabilities, which are that the higher probability for a regime, the more the winners in the regime are invested in. In the process of the 
probability-dependent investment decision, DSA1 and M-DSA1 are investing 100\% in winners of the regime with the highest state probability, and DSA2 and M-DSA2 are investing in winners weighted based on the state probabilities of each regime. As I mentioned above, the state probabilities used for the dynamic style allocations in this paper are the smoothed probability and recursive filtered probability. The smoothed probability can be exploited for in-sample analysis, as it is estimated from the full sample, and recursive filtered probability can be exploited for out-ofsample analysis as it is recursively and newly estimated every time only from the information until that time.

In-sample results from dynamic style allocations based on the long-only FW style portfolios using the smoothed probabilities are presented in Panel A of <Table 9>. The average returns on all dynamic style allocations are $2.081 \% \sim 2.217 \%$, which are higher than the return of value (2.066\%), the best performer in the entire sample period, as well as static style allocations (1.902\% 2.015\%). Thus, an investor can earn a market-adjusted return of $16.4 \%$ per year by the best dynamic strategy, DSA1 of CCI growth rate regimes. This DSA1 can also additionally generate approximately $2 \%$ more per year, in comparison with value investment during the sample period. Furthermore, downside risks of DSA1 of CCI growth rate, such as downside STD and longest drawdown, are lower than those of value investment, and reward-to-risk ratios of DSA1 of CCI growth rate such as Sharpe ratio (0.160), IR (0.216), and Sortino ratio (0.269) are higher than those of value investment, $0.145,0.197$, and 0.233 , respectively. All dynamic style allocations including DSA1 of CCI growth rate have a Sharpe ratio ranging from 0.149 to 0.165 , IR ranging from 0.198 to 0.218 , and Sortino ratio ranging from 0.227 to 0.269 , which are higher than those of all equivalent static strategies. Considering the Sharpe ratio of the KOSPI index, 0.024, the reward to risk of dynamic strategies is enormous.

I also construct equal out-of-sample dynamic style allocations. According to Lee and Kim (2017a), as MSMs used in this paper are effective to estimate the parameters following the changes of model structures to forecast, which is challenging for other studies, the out-of-sample approach under regime switching is expected to have better predictive ability. For the out-of-sample strategy at time $t$, I use recursive filtered probabilities at time $t$ - 1 which are newly calculated at every time $t$ - 1 with information until time $t$-1, and also newly find the winners in each of regimes at every time $t$ - 1 over past period. That is, styles $\mathrm{A} \sim \mathrm{F}$ are newly identified at every time $t-1$ with returns over the past period. As I need many observations to identify the winners, I start the dynamic style allocations five years after beginning of sample, 1992. And then, equal strategies, DSA1, DSA2, M-DSA1, and M-DSA2 are assessed. In practice, the superior results from the in-sample analysis continue in my out-of- 
This table shows performances of dynamic style allocations using the long-only FW style portfolios. Panels A and B present the results using the smoothed and the recursive filtered probability. The market-adjusted returns are the portfolio's monthly returns minus the monthly returns on the KOSPI index. The Sharpe ratio refers to the excess returns divided by the STD. IR is the market-adjusted returns divided by their standard deviations. Downside STD is the semi-deviation of excess returns with respect to a threshold of zero. The Sortino ratio is the average excess returns divided by the downside STD. The maximum drawdown and the duration of the longest drawdown in months are presented. The $t$-statistics are reported in parentheses. The sample period is from July 1987 to June 2017.

\begin{tabular}{|c|c|c|c|c|c|c|c|c|c|c|c|c|c|c|c|c|c|c|c|}
\hline & & \multicolumn{9}{|c|}{ Panel A: In-sample } & \multicolumn{9}{|c|}{ Panel B: Out-of-sample } \\
\hline & & Mean & STD & $\begin{array}{l}\text { Mrk- } \\
\text { adj. } \\
\text { return }\end{array}$ & $\begin{array}{c}\text { Sharpe } \\
\text { ratio }\end{array}$ & IR & $\begin{array}{c}\text { Down- } \\
\text { side } \\
\text { STD }\end{array}$ & $\begin{array}{c}\text { Sortino } \\
\text { ratio }\end{array}$ & $\begin{array}{c}\text { Max. } \\
\text { draw- } \\
\text { down }\end{array}$ & $\begin{array}{c}\text { Longest } \\
\text { draw } \\
\text { down }\end{array}$ & Mean & STD & $\begin{array}{l}\text { Mrk- } \\
\text { adj. } \\
\text { return }\end{array}$ & $\begin{array}{c}\text { Sharpe } \\
\text { ratio }\end{array}$ & IR & $\begin{array}{c}\text { Down- } \\
\text { side } \\
\text { STD } \\
\end{array}$ & $\begin{array}{c}\text { Sortino } \\
\text { ratio }\end{array}$ & $\begin{array}{c}\text { Max. } \\
\text { draw- } \\
\text { down }\end{array}$ & $\begin{array}{c}\text { Longest } \\
\text { draw } \\
\text { down }\end{array}$ \\
\hline \multirow{4}{*}{$\begin{array}{l}\text { KOSPI } \\
\text { index } \\
\text { Return }\end{array}$} & DSA1 & $\begin{array}{c}2.111 \\
(4.12)\end{array}$ & 9.732 & $\begin{array}{r}1.259 \\
(3.87)\end{array}$ & 0.149 & 0.204 & 6.040 & 0.241 & -27.351 & 24 & $\begin{array}{r}2.093 \\
(4.09)\end{array}$ & 9.717 & $\begin{array}{l}1.241 \\
(3.82)\end{array}$ & 0.148 & 0.201 & 6.035 & 0.238 & -27.351 & 35 \\
\hline & DSA2 & $\begin{array}{l}2.107 \\
(4.11)\end{array}$ & 9.734 & $\begin{array}{r}1.256 \\
(3.85)\end{array}$ & 0.149 & 0.203 & 6.038 & 0.240 & -27.351 & 24 & $\begin{array}{r}2.091 \\
(4.08)\end{array}$ & 9.733 & $\begin{array}{r}1.239 \\
(3.81)\end{array}$ & 0.147 & 0.201 & 6.031 & 0.238 & -27.351 & 35 \\
\hline & M-DSA1 & $\begin{array}{l}2.083 \\
(4.48)\end{array}$ & 8.827 & $\begin{array}{r}1.231 \\
(4.05)\end{array}$ & 0.162 & 0.213 & 5.568 & 0.256 & -20.694 & 21 & $\begin{array}{r}2.044 \\
(4.4)\end{array}$ & 8.815 & $\begin{array}{r}1.192 \\
(3.92)\end{array}$ & 0.157 & 0.206 & 5.558 & 0.248 & -20.694 & 18 \\
\hline & M-DSA2 & $\begin{array}{r}2.085 \\
(4.48)\end{array}$ & 8.836 & $\begin{array}{c}1.234 \\
(4.05)\end{array}$ & 0.162 & 0.213 & 5.557 & 0.257 & -20.687 & 21 & $\begin{array}{c}2.053 \\
(4.41)\end{array}$ & 8.833 & $\begin{array}{r}1.202 \\
(3.94)\end{array}$ & 0.158 & 0.208 & 5.547 & 0.251 & -20.687 & 18 \\
\hline \multirow{4}{*}{$\begin{array}{l}\text { CCI } \\
\text { growth } \\
\text { rate }\end{array}$} & DSA1 & $\begin{array}{l}2.217 \\
(4.31)\end{array}$ & 9.750 & $\begin{array}{r}1.366 \\
(4.09)\end{array}$ & 0.160 & 0.216 & 5.810 & 0.269 & -27.350 & 22 & $\begin{array}{r}2.174 \\
(-4.44)\end{array}$ & 9.298 & $\begin{array}{r}1.322 \\
-(4.16)\end{array}$ & 0.163 & 0.219 & 5.718 & 0.265 & -27.338 & 21 \\
\hline & DSA2 & $\begin{array}{r}2.179 \\
(4.25)\end{array}$ & 9.721 & $\begin{array}{r}1.327 \\
(4.01)\end{array}$ & 0.157 & 0.211 & 5.714 & 0.266 & -27.351 & 24 & $\begin{array}{r}2.187 \\
(-4.44)\end{array}$ & 9.338 & $\begin{array}{r}1.335 \\
-(4.16)\end{array}$ & 0.164 & 0.219 & 5.772 & 0.265 & -27.351 & 23 \\
\hline & M-DSA1 & $\begin{array}{r}2.139 \\
(4.39)\end{array}$ & 9.246 & $\begin{array}{r}1.287 \\
(3.95)\end{array}$ & 0.160 & 0.208 & 5.809 & 0.255 & -24.117 & 17 & $\begin{array}{l}2.094 \\
(4.27)\end{array}$ & 9.299 & $\begin{array}{r}1.243 \\
(3.78)\end{array}$ & 0.155 & 0.199 & 6.058 & 0.237 & -24.111 & 18 \\
\hline & M-DSA2 & $\begin{array}{r}2.118 \\
(4.35)\end{array}$ & 9.239 & $\begin{array}{r}1.266 \\
(3.91)\end{array}$ & 0.158 & 0.206 & 5.787 & 0.253 & -24.117 & 19 & $\begin{array}{l}2.100 \\
(4.27)\end{array}$ & 9.329 & $\begin{array}{r}1.248 \\
(3.78)\end{array}$ & 0.155 & 0.199 & 6.082 & 0.237 & -24.117 & 18 \\
\hline \multirow{4}{*}{$\begin{array}{l}\text { LCI } \\
\text { growth } \\
\text { rate }\end{array}$} & DSA1 & $\begin{array}{l}2.135 \\
(4.23)\end{array}$ & 9.571 & $\begin{array}{r}1.284 \\
(3.76)\end{array}$ & 0.155 & 0.198 & 6.496 & 0.228 & -25.995 & 36 & $\begin{array}{l}2.058 \\
(4.18)\end{array}$ & 9.345 & $\begin{array}{r}1.207 \\
(3.73)\end{array}$ & 0.150 & 0.197 & 5.975 & 0.235 & -27.335 & 24 \\
\hline & DSA2 & $\begin{array}{l}2.135 \\
(4.23)\end{array}$ & 9.580 & $\begin{array}{l}1.283 \\
(3.75)\end{array}$ & 0.154 & 0.198 & 6.507 & 0.227 & -25.995 & 36 & $\begin{array}{l}2.085 \\
(4.22)\end{array}$ & 9.385 & $\begin{array}{c}1.234 \\
(3.79)\end{array}$ & 0.152 & 0.200 & 5.968 & 0.240 & -27.351 & 24 \\
\hline & M-DSA1 & $\begin{array}{l}2.100 \\
(4.56)\end{array}$ & 8.745 & $\begin{array}{l}1.249 \\
(3.97)\end{array}$ & 0.165 & 0.209 & 5.684 & 0.254 & -20.240 & 16 & $\begin{array}{l}2.006 \\
(4.36)\end{array}$ & 8.734 & $\begin{array}{l}1.155 \\
(3.78)\end{array}$ & 0.155 & 0.199 & 5.679 & 0.238 & -23.455 & 19 \\
\hline & M-DSA2 & $\begin{array}{r}2.102 \\
(4.56)\end{array}$ & 8.751 & $\begin{array}{r}1.251 \\
(3.97)\end{array}$ & 0.165 & 0.209 & 5.683 & 0.255 & -20.258 & 16 & $\begin{array}{r}2.024 \\
(4.4)\end{array}$ & 8.739 & $\begin{array}{r}1.173 \\
(3.83)\end{array}$ & 0.157 & 0.202 & 5.651 & 0.242 & -23.462 & 19 \\
\hline \multirow{4}{*}{$\begin{array}{l}\text { GDP } \\
\text { growth } \\
\text { rate }\end{array}$} & DSA1 & $\begin{array}{l}2.116 \\
(4.28)\end{array}$ & 9.380 & $\begin{array}{l}1.265 \\
(4.09)\end{array}$ & 0.156 & 0.215 & 5.722 & 0.255 & -26.967 & 24 & $\begin{array}{r}2.109 \\
(4.3)\end{array}$ & 9.312 & $\begin{array}{l}1.258 \\
(4.07)\end{array}$ & 0.156 & 0.215 & 5.783 & 0.251 & -26.767 & 24 \\
\hline & DSA2 & $\begin{array}{l}2.155 \\
(4.28)\end{array}$ & 9.551 & $\begin{array}{l}1.303 \\
(4.13)\end{array}$ & 0.157 & 0.218 & 5.791 & 0.259 & -27.351 & 24 & $\begin{array}{l}2.143 \\
(4.29)\end{array}$ & 9.476 & $\begin{array}{l}1.292 \\
(4.03)\end{array}$ & 0.157 & 0.212 & 5.800 & 0.256 & -27.351 & 24 \\
\hline & M-DSA1 & $\begin{array}{l}2.081 \\
(4.28)\end{array}$ & 9.219 & $\begin{array}{r}1.230 \\
(3.82)\end{array}$ & 0.155 & 0.201 & 6.030 & 0.236 & -23.871 & 20 & $\begin{array}{l}2.064 \\
(4.27)\end{array}$ & 9.166 & $\begin{array}{r}1.213 \\
(3.77)\end{array}$ & 0.154 & 0.199 & 6.023 & 0.234 & -23.743 & 20 \\
\hline & M-DSA2 & $\begin{array}{l}2.100 \\
(4.27)\end{array}$ & 9.321 & $\begin{array}{l}1.248 \\
(3.83)\end{array}$ & 0.155 & 0.202 & 6.112 & 0.236 & -24.117 & 21 & $\begin{array}{l}2.081 \\
(4.26)\end{array}$ & 9.276 & $\begin{array}{r}1.229 \\
(3.73)\end{array}$ & 0.154 & 0.196 & 6.115 & 0.233 & -24.117 & 20 \\
\hline
\end{tabular}


sample analysis. In Panel B of $<$ Table 9>, the average returns on all DSA1 and DSA2 are $2.095 \% \sim 2.187 \%$, which are also higher than returns of any single style or static strategy. For example, Panel A of <Table 10> shows comparison of the performances of representative dynamic strategy, DSA2 of CCI regimes, with those of nine single styles. Mean difference of table is average of returns on DSA2 minus returns on the style. Every mean difference is positive, which validates that dynamic strategies are superior to single styles. All mean differences are significant except comparison with value and size. While the positive differences between DSA2 and size/value are not significant, Sharpe ratios of DSA2 highly increase by $13.9 \%$ and $13.1 \%$, and IRs of DSA2 also increase by $28.8 \%$ and $11.2 \%$ from those of size and value. Reward-to-risk ratios in the out-of-sample analysis are very similar to those in the in-sample analysis.

\section{$\langle$ Table 10> Comparison of Performances between Dynamic Strategies and Single Styles}

This table shows comparison of performances of the representative out-of-sample dynamic style allocations with those of nine single styles. Panel A presents the comparison between DSA2 of CCI regimes and nine single styles using the long-only FW portfolios, and Panel B presents the comparison between DSA2 of LCI regimes and single styles using the longshort VW portfolios. Mean difference is average of DSA2 returns minus style returns. Growth of Sharpe ratio and Growth of IR refer to percentage of growth rate of DSA2 Sharpe ratio and IR against single style. The $t$-statistics are reported in parentheses. The sample period is from July 1987 to June 2017.

\begin{tabular}{|c|c|c|c|c|c|}
\hline \multirow[b]{2}{*}{ Style } & \multicolumn{3}{|c|}{ Panel A: Long-only FW portfolios } & \multicolumn{2}{|c|}{ Panel B: Long-short VW portfolios } \\
\hline & $\begin{array}{c}\text { Mean } \\
\text { difference }\end{array}$ & $\begin{array}{l}\text { Growth of } \\
\text { Sharpe ratio }\end{array}$ & $\begin{array}{l}\text { Growth } \\
\text { of IR }\end{array}$ & $\begin{array}{c}\text { Mean } \\
\text { difference }\end{array}$ & $\begin{array}{l}\text { Growth } \\
\text { of IR }\end{array}$ \\
\hline Size & $\begin{array}{l}0.141 \\
(1.46)\end{array}$ & 13.89 & 28.82 & $\begin{array}{l}1.046 \\
(2.31)\end{array}$ & 726.67 \\
\hline Value & $\begin{array}{l}0.121 \\
(1.37)\end{array}$ & 13.10 & 11.17 & $\begin{array}{l}0.415 \\
(1.77)\end{array}$ & 27.18 \\
\hline Momentum & $\begin{array}{l}1.038 \\
(4.04)\end{array}$ & 198.18 & 313.21 & $\begin{array}{r}1.753 \\
(4.7)\end{array}$ & $-\rightarrow+$ \\
\hline $\begin{array}{l}\text { Low } \\
\text { volatility }\end{array}$ & $\begin{array}{l}0.355 \\
(1.76)\end{array}$ & 1.86 & 15.87 & $\begin{array}{l}0.447 \\
(1.81)\end{array}$ & 90.77 \\
\hline Low beta & $\begin{array}{c}0.316 \\
(1.82)\end{array}$ & 2.50 & 27.33 & $\begin{array}{l}1.217 \\
(3.14)\end{array}$ & 1027.27 \\
\hline Profitability & $\begin{array}{l}0.491 \\
(2.56)\end{array}$ & 29.13 & 31.93 & $\begin{array}{l}0.883 \\
(2.75)\end{array}$ & 175.56 \\
\hline Investment & $\begin{array}{l}0.458 \\
(2.75)\end{array}$ & 37.82 & 37.74 & $\begin{array}{l}1.074 \\
(3.22)\end{array}$ & 222.08 \\
\hline Quality & $\begin{array}{l}0.384 \\
(2.28)\end{array}$ & 18.84 & 18.38 & $\begin{array}{l}0.678 \\
(2.06)\end{array}$ & 55.00 \\
\hline Dividend & $\begin{array}{l}0.254 \\
(1.70)\end{array}$ & 11.56 & 12.31 & $\begin{array}{l}0.497 \\
(1.86)\end{array}$ & 40.11 \\
\hline
\end{tabular}


Thus, out-of-sample dynamic style allocations in this paper can also improve the performances, unlike in other studies that fail to make innovation in the out-of-sample prediction despite good results from the in-sample analysis.

Performances from in-sample dynamic style allocations using the long-short VW portfolios are shown in Panel A of <Table 11>. DSA1 and DSA2 involving only the first winners in each regime generate average monthly returns range from $1.071 \%$ to $1.304 \%$, which are much higher than returns of equivalent static allocations, $0.698 \%$ $0.931 \%$, as well as all long-short VW portfolios for single styles (at best, $0.942 \%$ from value). This means that the dynamic style allocation strategy can maximally produce $4.3 \%$ more per year than the best performing long-short style portfolio and value and that an investor can earn $15.65 \%$ per year by this strategy with zero-investment costs. M-DSA1 and M-DSA2 using the six best styles also have higher average returns of $0.967 \% \sim 1.185 \%$ than all static allocations and single-style portfolios. Furthermore, from reward-to-risk ratios, the performances of dynamic style allocations are more stable. IRs of dynamic strategies using long-short VW portfolios are 0.216 0.295, which are larger than IRs of equivalent static allocations and increased by $51.3 \%$ from the highest IR among the single-style long-short VW portfolios, 0.195. In addition, the Sortino ratio of dynamic style allocations is $0.321 \sim 0.469$, which is higher than the highest Sortino ratio (value) among the single-style long-short VW portfolios, 0.302. Although dynamic approaches do not seem to have lower downside risk than static approaches according to the drawdown analysis, they compensate enough with their performances. In addition, taking the Sortino ratio (0.039) and the Sharpe ratio (0.024) of the KOSPI index into account, the dynamic allocations using factors provide for more effective diversification than asset diversification.

These results from in-sample dynamic style allocations using the long-short VW portfolios are consistent with the results from the out-of-sample prediction in Panel B of <Table 11>. DSA1 and DSA2 of out-of-sample dynamic strategies have average returns range from $1.034 \%$ to $1.357 \%$; hence, they can generate up to $5 \%$ per year outperformance over value long-short VW portfolios. Moreover, they have IRs ranging from 0.222 to 0.302 and Sortino ratios ranging from 0.312 to 0.481 , which are larger than or similar to the in-sample prediction. Panel B of <Table 10> presents comparison of the performances between DSA2 of LCI regimes and nine single styles. All mean differences in Panel B are significantly positive, which confirms again the superiority of dynamic strategies. Growth rates of IR are very high, larger than $27 \%$. Thus, the outperformance of dynamic style allocations under regime shifts are robust both in in-sample and out-of-sample analyses. 


\section{〈Table 11〉 Performances of Dynamic Style Allocation Strategies Using the Long-Short VW Style Portfolios}

This table shows performances of dynamic style allocations using the long-short VW style portfolios. Panels A and B present the results using the smoothed and the recursive filtered probability. IR is average returns on long-short portfolios divided by their standard deviations. Downside STD is the semi-deviation of average returns on long-short portfolios with respect to a threshold of zero. The Sortino ratio is the average returns on long-short portfolios divided by the downside STD. In addition, the maximum drawdown and the duration of the longest drawdown in months are presented. The $t$-statistics are reported in parentheses. The sample period is from July 1987 to June 2017

\begin{tabular}{|c|c|c|c|c|c|c|c|c|c|c|c|c|c|c|c|}
\hline & & \multicolumn{7}{|c|}{ Panel A: In-sample } & \multicolumn{7}{|c|}{ Panel B: Out-of-sample } \\
\hline & & Mean & STD & IR & $\begin{array}{l}\text { Downside } \\
\text { STD }\end{array}$ & $\begin{array}{l}\text { Sortino } \\
\text { ratio }\end{array}$ & $\begin{array}{c}\text { Max. } \\
\text { drawdown }\end{array}$ & $\begin{array}{l}\text { Longest } \\
\text { drawdown }\end{array}$ & Mean & STD & IR & $\begin{array}{c}\text { Downside } \\
\text { STD }\end{array}$ & $\begin{array}{l}\text { Sortino } \\
\text { ratio }\end{array}$ & $\begin{array}{c}\text { Max. } \\
\text { drawdown }\end{array}$ & $\begin{array}{l}\text { Longest } \\
\text { drawdown }\end{array}$ \\
\hline \multirow{4}{*}{$\begin{array}{c}\text { KOSPI } \\
\text { index } \\
\text { Return }\end{array}$} & DSA1 & $\begin{array}{l}1.251 \\
(4.57)\end{array}$ & 5.192 & 0.241 & 3.600 & 0.348 & -27.854 & 68 & $\begin{array}{l}1.197 \\
(4.47)\end{array}$ & 5.081 & 0.235 & 3.591 & 0.333 & -27.822 & 69 \\
\hline & DSA2 & $\begin{array}{l}1.216 \\
(4.35)\end{array}$ & 5.304 & 0.229 & 3.721 & 0.327 & -27.854 & 68 & $\begin{array}{l}1.264 \\
(4.46)\end{array}$ & 5.377 & 0.235 & 3.822 & 0.331 & -27.854 & 68 \\
\hline & M-DSA1 & $\begin{array}{l}1.185 \\
(5.13)\end{array}$ & 4.380 & 0.271 & 3.168 & 0.374 & -24.614 & 66 & $\begin{array}{l}1.129 \\
(5.64)\end{array}$ & 3.800 & 0.297 & 2.415 & 0.467 & -16.802 & 66 \\
\hline & M-DSA2 & $\begin{array}{l}1.160 \\
(4.97)\end{array}$ & 4.432 & 0.262 & 3.251 & 0.357 & -24.614 & 66 & $\begin{array}{l}1.174 \\
(5.72)\end{array}$ & 3.889 & 0.302 & 2.455 & 0.478 & -16.816 & 66 \\
\hline \multirow{4}{*}{$\begin{array}{l}\mathrm{CCI} \\
\text { growth } \\
\text { rate }\end{array}$} & DSA1 & $\begin{array}{l}1.090 \\
(5.00)\end{array}$ & 4.135 & 0.263 & 2.530 & 0.431 & -14.629 & 69 & $\begin{array}{l}1.034 \\
(4.78)\end{array}$ & 4.101 & 0.252 & 2.510 & 0.412 & -13.906 & 74 \\
\hline & DSA2 & $\begin{array}{l}1.100 \\
(4.72)\end{array}$ & 4.418 & 0.249 & 2.639 & 0.417 & -14.663 & 69 & $\begin{array}{l}1.067 \\
(4.70)\end{array}$ & 4.304 & 0.248 & 2.582 & 0.413 & -14.663 & 75 \\
\hline & M-DSA1 & $\begin{array}{l}0.988 \\
(4.71)\end{array}$ & 3.980 & 0.248 & 2.623 & 0.377 & -14.374 & 70 & $\begin{array}{l}0.919 \\
(4.31)\end{array}$ & 4.049 & 0.227 & 2.950 & 0.312 & -16.818 & 48 \\
\hline & M-DSA2 & $\begin{array}{l}1.004 \\
(4.63)\end{array}$ & 4.116 & 0.244 & 2.674 & 0.375 & -14.368 & 70 & $\begin{array}{l}0.935 \\
(4.31)\end{array}$ & 4.121 & 0.227 & 2.921 & 0.320 & -16.816 & 71 \\
\hline \multirow{3}{*}{$\begin{array}{l}\text { LCI } \\
\text { growth } \\
\text { rate }\end{array}$} & DSA1 & $\begin{array}{l}1.304 \\
(4.57)\end{array}$ & 5.413 & 0.241 & 3.816 & 0.342 & -27.854 & 68 & $\begin{array}{l}1.317 \\
(4.65)\end{array}$ & 5.373 & 0.245 & 3.794 & 0.347 & -27.624 & 70 \\
\hline & M-DSA1 & $\begin{array}{l}1.162 \\
(5.59)\end{array}$ & 3.945 & 0.295 & 2.494 & 0.466 & -16.816 & 66 & $\begin{array}{l}1.106 \\
(5.36)\end{array}$ & 3.915 & 0.283 & 2.497 & 0.443 & -16.701 & 68 \\
\hline & M-DSA2 & $\begin{array}{l}1.165 \\
(5.60)\end{array}$ & 3.951 & 0.295 & 2.485 & 0.469 & -16.816 & 66 & $\begin{array}{l}1.150 \\
(5.50)\end{array}$ & 3.969 & 0.290 & 2.499 & 0.460 & -16.816 & 68 \\
\hline \multirow{4}{*}{$\begin{array}{l}\text { GDP } \\
\text { growth } \\
\text { rate }\end{array}$} & DSA1 & $\begin{array}{l}1.077 \\
(4.35)\end{array}$ & 4.700 & 0.229 & 3.003 & 0.358 & -22.946 & 33 & $\begin{array}{l}1.101 \\
(4.36)\end{array}$ & 4.795 & 0.230 & 3.039 & 0.362 & -20.794 & 33 \\
\hline & DSA2 & $\begin{array}{l}1.071 \\
(4.10)\end{array}$ & 4.958 & 0.216 & 3.335 & 0.321 & -26.369 & 43 & $\begin{array}{l}1.171 \\
(4.21)\end{array}$ & 5.273 & 0.222 & 3.392 & 0.345 & -26.369 & 33 \\
\hline & M-DSA1 & $\begin{array}{l}0.967 \\
(4.97)\end{array}$ & 3.692 & 0.262 & 2.410 & 0.401 & -12.565 & 45 & $\begin{array}{l}1.022 \\
(5.18)\end{array}$ & 3.744 & 0.273 & 2.125 & 0.481 & -12.870 & 69 \\
\hline & M-DSA2 & $\begin{array}{l}1.012 \\
(5.07)\end{array}$ & 3.786 & 0.267 & 2.457 & 0.412 & -12.841 & 43 & $\begin{array}{l}1.057 \\
(5.13)\end{array}$ & 3.909 & 0.270 & 2.249 & 0.470 & -15.658 & 66 \\
\hline
\end{tabular}


Overall, regime-dependent dynamic style allocations outperform the market, any single-style portfolios, and static style allocations, regardless of macroeconomic variables for regime identification, with respect to average returns and reward-to-risk ratios. In particular, while the best single style and value have relatively higher returns and lower reward-to-risk ratios, and static style allocations relatively have lower returns and higher reward-to-risk ratios, dynamic style allocations have the highest returns and reward-to-risk ratios. These results are caused by timely style rotating or well-timed style rebalancing based on regime switching. That is, as I capture the patterns of the time-varying style premium through regime shifts, the weighting of style in portfolios can be adjusted according to the predicted regime, stably improving the performances. In addition, the improvedment effectiveness in style performances is stronger for the long-short approaches than the long-only approaches. Since the long-only approaches have relatively high exposure to the market, deviating from pure factor exposure, not only their underperforming but also their outperforming are limited. In contrast, the long-short approach facilitates reducing the correlation to the market, capturing pure factor premiums and effective factor diversification. Consequently, regime-dependent style allocations using long-short portfolios enhance their effectiveness in performance improvement more.

The above results are when styles are selected by their average returns for style allocations. In addition, I investigate equal regime-dependent dynamic style allocations, choosing the best performers in each of the regimes, style A-F, by IRs. The findings are that this strategy generates slightly higher reward-to-risk ratios than the above strategies, choosing the best performers by return ranking, but I do not report the results to save space.

For the actual application of the proposed dynamic strategy, investability is important, taking turnover and transaction costs into account. For the simplicity, I consider the style rotation strategy, DSA1. According to Ang and Bekaert (2004), regimeswitching strategies are relatively robust to transaction costs because they are designed to exploit low-frequency changes in expected returns and volatilities. Because the probability of staying within the same regime is relatively high, portfolio turnover is low. In this paper, all probabilities of persistence in the same normal regime are larger than 0.92. For example, each of the switching approaches based on LCI growth rate and CCI growth rate leads to only 5 and 15 rebalancing actions in 372 months in the period from July 1987 to June 2017, respectively, which are used to identify regimes for dynamic style allocations producing the best performance. Note that DSA1 using long-only FW style portfolios under CCI growth rate regimes annually produces excess returns of $16.4 \%$ over the market index and $2 \%$ over the longonly FW value portfolio and that DSA1 using long-short VW style portfolios under LCI growth rate regimes annually produces excess returns of $5 \%$ over the long-short 
VW value portfolio. Assuming transaction costs of $0.33 \%$ for a full round-trip, the performance for DSA 1 under CCI regimes is reduced by only $0.16 \%$ (or $0.32 \%$ for the long-short approach) per year and the performance under LCI regimes is reduced by only $0.05 \%$ (or $0.1 \%$ for the long-short approach) per year in the entire sample period. ${ }^{12}$ )

This implies that after accounting for transaction costs, the results remain stable and profitable.

Moreover, ETFs can be used for style portfolios to efficiently save on implementation cost. According to Morningstar (2017), Korea is the third largest smart beta market in terms of AUM, after Japan and Australia, and has the largest number of smart beta ETPs. Since the Korean smart beta ETPs market also continues to grow, trading volumes of style ETFs are increasing and ETFs can be useful investment vehicles to reduce transaction costs. There are various ETFs tracking style indices released by the Korea Exchange, such as the KOSPI 200 Value Tilt Index, KOSPI 200 Low Volatility Index, and KOSPI SmallCap. For example, the long-short size portfolio can be replicated by a long position in the KOSPI SmallCap and a short position in the KOSPI LargeCap. The long-only value portfolio can be replicated with a long position in the KOSPI 200 Value Tilt Index or KRX Smart Value Index, which is easier to implement than the long-short approach. If transaction costs of 0.03 round trip for ETFs are considered, the performances are more stable, as each of DSA1s under CCI regimes and under LCI regimes is reduced by only $0.015 \%$ (or $0.03 \%$ for the long-short approach) per year and $0.005 \%$ (or $0.01 \%$ for the long-short approach) per year. ${ }^{13)}$ Although the portfolios are rebalanced every month when ETFs are used for dynamic strategies, they outperform all of the style investment after transaction costs.

\section{Conclusion}

A number of studies report that outperforming of styles is not stable over time, and different styles demonstrate disparate time-varying performance. Therefore, I assess the time-varying style premium in the Korean stock market and analyze the dynamic style allocation strategies based on the time variations under regime switching. To investigate the style or factor investing, I construct the long-only and the long-short portfolios for various styles, which are weighted by fundamentals or market capitalization. Styles discussed in this paper include size, value, momentum, low volatility, low beta, profitability, investment, quality, and dividend.

12) The transaction taxes on the Korea Exchange are $0.3 \%$ (only for selling). In general, trading fees charged by securities companies in Korea are $0.01 \sim 0.015 \%$ on HTS or MTS. I assume trading fees of $0.03 \%$ $(0.015 \%$ for selling or buying), and then total transaction costs of $0.33 \%$ round trip. If trading fees of $0.01 \%$ are applied, performances after transaction costs are improved.

13) In the Korean ETF market, trading fees depend on securities companies, trading volumes, how to trade, etc. Generally, minimum trading fees are $0.015 \%$ for buying or selling, and transaction taxes are exempted. 
I find that value and size are the best performers among the long-only FW approaches and value and low volatility are the best performers among the long-short VW approaches during the entire sample period. However, in the subperiod analysis, performance rankings across styles change. For instance, although value is the best in three subperiods in the long-only FW strategy, it is the worst during July 2007June 2012. Size, low beta, and low volatility are also placed in best or the worst performers depending on the time and the weighting scheme. Thus, time-varying style rankings support that dynamic style allocations can produce superior or stable profits.

In addition, the long-only approaches have different correlation matrices with the long-short approaches. The long-short approach correlates with the market less; therefore, it facilitates effective factor diversification, yet correlation coefficients across the long-only portfolios are relatively high, implying that the long-only portfolios fail to independently represent exposure to the intended factors or to capture pure factor premiums. These portfolios hold many stocks involved in other styles. In contrast, styles weakly correlate across the long-short portfolios. Further, for the equivalent style, the long-only portfolios are weakly correlated with the long-short. Hence, long-short portfolios enable providing the exposure to the intended factors more and effective factor diversification.

To capture the time variations of the style premium depending on the market condition and to build dynamic style allocations, economic regimes are identified using the Markov-switching model, and I assess the style performances in each regime. Four macroeconomic variables related to stock market returns, business cycle, or economic situation are exploited in the models, which are the KOSPI index return, the CCI growth rate, the LCI growth rate, and the GDP growth rate. The evidence shows that low beta and low volatility styles produce superior returns in the event state and that value and dividend styles outperform in the normal states.

Based on the performances of styles by regimes and the state probabilities, I build the dynamic style allocation strategies using long-only FW and long-short VW style portfolios and compare them with market returns, static equivalent strategies, and single-style portfolios. As a result, my dynamic style allocations outperform all other portfolios both before and after transaction costs. The dynamic style allocations using long-only FW portfolios produce excess returns of at best $16.4 \%$ per year over the market index and $2 \%$ per year over the best single-style portfolio. In addition, the dynamic strategies using long-short VW style portfolios annually produce excess returns of at best $5 \%$ over the best single-style long-short portfolio. Moreover, they also have higher reward-to-risk ratios than any single-style portfolios or static equivalent strategies. These outperformances are consistent in both in-sample and out-of-sample prediction analyses. 


\section{References}

Ahmed, P., L. J. Lockwood, and S. Nanda, 2002, Multistyle rotation strategies, Journal of Portfolio Management 28 (3), pp. 17-29.

Amenc, N., F. Goltz, and V. Le Sourd, 2009, The performance of characteristics-based indices, European Financial Management 15 (2), pp. 241-278.

Amenc, N., P. Malaise, L. Martellini, and D. Sfeir, 2003, Tactical style allocation: A new form of market neutral strategy, Journal of Alternative Investments 6 (1), pp. 8-22.

Ammann, M. and M. Verhofen, 2006, The effect of market regimes on style allocation, Financial Markets and Portfolio Management 20 (3), pp. 309-337.

Ang, A. and G. Bekaert, 2002, International asset allocation with regime shifts, Review of Financial Studies 15 (4), pp. 1137-1187.

Ang, A. and G. Bekaert, 2004, How do regimes affect asset allocation, Financial Analyst Journal, 60 (2), pp. 86-99.

Ang, A. and A. Timmermann, 2012, Regime changes and financial markets, Annual Review of Financial Economics 4, pp. 313-337.

Arnott, R. D., N. Beck, and V. Kalesnik. 2017, Forecasting factor and smart beta returns, Research Affiliates (February).

Arnott, R. D. and J. Hsu, 2007, Noise, CAPM, and the size and value effects, Journal of Investment Management 5 (1), pp. 1-11.

Arshanapalli, B. G., T. D. Coggin, and J. Doukas, 1998, Multifactor asset pricing analysis of international value investment strategies, Journal of Portfolio Management 24 (4), pp. 10-23.

Arshanapalli, B. G., E. D. Ouville, and W. Nelson, 2004, Are size, value, and momentum related to recession risk?, Journal of Investing 13 (4), pp. 83-87.

Arshanapalli, B. G., L. N. Switzer, and K. Panju, 2007, Equity-style timing: a multi-style rotation model for the Russell large-cap and small-cap growth and value style indexes, Journal of Asset Management 8 (1), pp. 9-23.

Asness, C., 2006, The value of fundamental indexing, Institutional Investor Magazine 40 (10), pp. 94-97.

Asness, C., A. Frazzini, and L. H. Pedersen, 2017, Quality Minus Junk, Working Paper.

Asness, C., T. J. Moskowitz, and L. H. Pedersen, 2013, Value and momentum everywhere, Journal of Finance 88 (3), pp. 929-985.

Barber, B. M. and J. D. Lyon, 1997, Firm-size, book-to-market-ratio, and security returns: a holdout sample of financial firms, Journal of Finance 52 (2), pp. 875-883.

Beckers, S. and J. A. Thomas, 2010, On the persistence of style returns, Journal of Portfolio Management 37 (1), pp. 15-30. 
Black, A. J. and D. G. McMillan, 2005, Value and growth stocks and cyclical asymmetries, Journal of Asset Management 6 (2), pp. 104-116.

Blitz, D., J. Huij, S. Lansdorp, and P. van Vliet, 2014, Factor investing: long-only versus long-short, Working Paper.

Blume, M. E., 1980, Stock returns and dividend yields: some more evidence, Review of Economics and Statistics 62 (4), pp. 567-577.

Capaul, C., I. Rowley, and W. F. Sharpe, 1993, International value and growth stock returns, Financial Analysts Journal 49 (1), pp. 27-36.

Carhart, M., 1997, On persistence in mutual fund performance, Journal of Finance $52(1)$, pp. 57-82.

Chae, J. and Y. Eom, 2009, Negative momentum profit in korea and its sources, AsiaPacific Journal of Financial Studies 38 (2), pp. 211-236.

Chan, L. K. C., J. Karceski, and J. Lakonishok, 1999, On portfolio optimization: forecasting covariances and choosing the risk model, Review of Financial Studies 12 (5), pp. 937-974.

Chen, C., R. Chen, and G. W. Bassett, 2007, Fundamental indexation via smoothed cap weights, Journal of Banking and Finance 31 (11), pp. 3486-3502.

Clarke, R., H. de Silva, and S. Thorley, 2006, Minimum-variance portfolios in the US equity market, Journal of Portfolio Management 33 (1), pp. 10-24.

Copeland, M. and T. Copeland, 1999, Market timing: style and size rotation using the VIX, Financial Analysts Journal 55 (2), pp. 73-81.

Estrada, J., 2008, Fundamental indexation and international diversification, Journal of Portfolio Management 34 (3), pp. 93-109.

Fama, E. and K. R. French, 1988, Dividend yields and expected stock returns, Journal of Financial Economics 22 (1), pp. 3-25.

Fama, E. and K. R. French, 1992, The Cross-section of expected stock returns, Journal of Finance 47 (2), pp. 427-465.

Fama, E. and K. R. French, 1993, Common risk factors in the returns on stocks and bonds, Journal of Financial Economics 33 (1), pp. 3-56.

Fama, E. and K. R. French, 2015, A five-factor asset pricing model, Journal of Financial Economics 116 (1), pp. 1-22.

Frazzini, A. and L. H. Pedersen, 2014, Betting against beta, Journal of Financial Economics 111 (1), pp. 1-25.

French, K. R., 2017, http://mba.tuck.dartmouth.edu/pages/faculty/ken.french/data_library.html. Glushkov, D., 2015, How smart are "smart beta" ETFs. Analysis of relative performance and factor exposure, Working Paper.

Guidolin, M. and A. Timmermann, 2008, International asset allocation under regime 
switching, skew, and kurtosis preferences, Review of Financial Studies 21 (2), pp. 889-935.

Gupta, A., A. Kassam, R. Suryanarayanan, and K. Varga, 2014, Index performance in changing economic environments, MSCI Research.

Hamilton, J. D., 1989, A new approach to the economic analysis of nonstationary time series and the business cycle, Econometrica 57 (2), pp. 357-384.

Hammerschmid, R. and H. Lohre, 2014, Regime shifts and stock return predictability, Working Paper.

Haugen, R. A. and N. L. Baker, 1991, The efficient market inefficiency of capitalization-weighted stock portfolios, Journal of Portfolio Management 17 (3), pp. 35-40.

Hodnett, K., 2014, Value-growth timing: evidence from the johannesburg stock exchange, Journal of Applied Business Research 30 (6), pp. 1939-194.

Hsu, J., 2006, Cap-weighted portfolios are sub-optimal portfolios, Journal of Investment Management 4 (3), pp. 1-10.

Ilmanen, A. and J. Kizer, 2012, The death of diversification has been greatly exaggerated, Journal of Portfolio Management 38 (3), pp. 15-27.

Jacobs, B. and K. Levy, 1996, High definition style rotation, Journal of Investing 5 (3), pp. 14-23.

Jagannathan, R. and T. Ma, 2003, Risk reduction in large portfolios: why imposing the wrong constraints helps, Journal of Finance 58 (4), pp. 1651-1684.

Jegadeesh, N. and S. Titman, 1993, Returns to buying winners and selling losers: implicafions for stock market efficiency, Journal of Finance 48 (1), pp. 65-91.

Jegadeesh, N. and S. Titman, 2001, Profitability of momentum strategies: an evaluation of alternative explanations, Journal of Finance 56 (2), pp. 699-720.

Kao, D. L. and R. D. Shumaker, 1999, Equity style timing, Financial Analysts Journal 55 (1), pp. 37-48.

Kaplan, P. D., 2008, Why fundamental indexation might—or might not—work, Financial Analysts Journal 64 (1), pp. 32-39.

Kho, B. C., 1997, Risk premium and profitability of relative strength strategies, Korean Journal of Financial Management 14, pp. 1-21.

Kritzman, M., S. Page, and D. Turkington, 2012, Regime Shifts: Implications for Dynamic Strategies, Financial Analysts Journal 68 (3), pp. 22-39.

Lakonishok, J., A. Shleifer, and R. W. Vishny, 1994, Contrarian investment, extrapolation and risk, Journal of Finance 49 (5), pp. 1541-1578.

La Porta, R., 1996, Expectations and the cross-section of stock returns, Journal of Finance 51 (5), pp. 1715-1742.

Lee, J. H. and R. Kim, 2017, The dynamic style allocation under the regime shifts: value vs growth, Asian Review of Financial Research 30 (3), pp. 103-135. 
Levis, M. and N. Tessaromatis, 2004, Style Rotation Strategies, Journal of Portfolio Management Summer 30 (4), pp. 160-169.

Lewellen, J., 1999, The time-series relations among expected return, risk and bookto-market, Journal of Financial Economics 54 (1), pp. 5-43.

Litzenberger, R. and K. Ramaswamy, 1979, The effects of personal taxes and dividends on capital asset prices: theory and empirical evidence, Journal of Financial Economics 7 (2), pp. 163-195.

Lucas, A., R. van Dijk, and T. Kloek, 2002, Stock selection, style rotation, and risk, Journal of Empirical Finance 9 (1), pp. 1-34.

Morningstar, 2017, A global guide to strategic-beta exchange-traded products, Morningstar Manager Research.

Naes, R., J. A. Skjeltorp, and B. A. Odegaard, 2011, Stock Market Liquidity and the Business Cycle, Journal of Finance 66 (1), pp. 139-176.

Oertmann, P., 2000, Why do value stocks earn higher returns than growth stocks, and vice versa?, Financial Markets and Portfolio Management 14, pp. 131-151.

Perold, A. F., 2007, Fundamentally flawed indexing, Financial Analysts Journal 63 (6), pp. 31-37.

Ranaldo, A. and R. Häberle, 2007, Wolf in sheep's clothing: the active investment strategies behind index performance, European Financial Management 14 (1), pp. $55-81$.

Titman, S., K. C. John Wei, and F. Xie, 2013, Market Development and the Asset Growth Effect: International Evidence, Journal of Financial and Quantitative Analysis 48 (5), pp. 1405-1432.

Vliet, P. V. and D. Blitz, 2011, Dynamic strategic asset allocation: Risk and return across the business cycle, Journal of Asset Management 12 (2), pp. 360-375.

Zhang, L., 2005, The value premium, Journal of Finance 60 (1), pp. 67-103. 


\title{
스타일전환에 따른 스마트베타전략과 롱-솟 요인투자전략*
}

\section{김 류 미 (서울대학교 증권금융연구소 객원연구원)**}

\author{
<요 약>
}

기존 문헌에 따르면 스타일 프리미엄은 시간에 따라 변동한다. 따라서, 특정 스타일이 언제나 상대적으로 높은 수익률을 내는 것은 아니며, 시기에 따라 우월한 스타일은 달라지게 된다. 이에, 본 연구에서는 국면전환모형을 이용하여 시기의 변화를 정의하고, 한국 주식을 대상으로 동태적 스타일배분전략을 세워 그 성과에 대해 분석하였다. 결과에 따르면, 가치, 규모, 저변동성 스타일이 전 표본 기간에서 성과가 가장 우수하지만 모든 국면에서 가장 우월한 것은 아니다. 변동성이 가장 큰 사건국면(event state)에서는 저변동성 스타일이, 그 외의 정상국면(normal state)에서는 가치와 배당 스타일이 가장 우수한 스타일로 보고되었다. 이러한 스타일 시변현상을 기반으로 국면에 따라 투자하는 스타일을 달리하는 동태적 스타일배분전략은 주식시장이나 정태적 전략, 그리고 단일 스타일 투자전략에 비해 더 높은 성과를 내었으며, 거래비용을 고려한 이후에도 결과 는 강건하였다. 이러한 성과는 표본내 분석과 표본외 분석 모두에서 동일하게 나타났다.

핵심 단어: 스타일 전환, 스마트베타전략, 요인투자, 국면전환모형, 동태적 전략 JEL 분류기호: G11, G12, C32

* 논문의 질을 높이는데 유익한 조언을 해주신 익명의 두 분 심사위원과 이준행 교수님께 진심으로 감사드립니다. 본 연구는 2017년 한국증권학회·미래에셋자산운용 신진학자 연구지원사업의 연구 지원을 받아 수행되었습니다.

** 연락담당 저자, 주소: 서울특별시 관악구 관악로 1 서울대학교 경영대학(원) 58동 413호, 08826; E-mail: atsam6@snu.ac.kr; Tel: 02-880-6855; Fax: 02-882-0547. 